Atmos. Chem. Phys., 18, 14477-14492, 2018

https://doi.org/10.5194/acp-18-14477-2018

(C) Author(s) 2018. This work is distributed under

the Creative Commons Attribution 4.0 License.

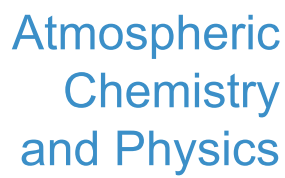

(c) (i)

\title{
Fluxes and sources of nutrient and trace metal atmospheric deposition in the northwestern Mediterranean
}

\author{
Karine Desboeufs $^{1}$, Elisabeth Bon Nguyen ${ }^{1}$, Servanne Chevaillier ${ }^{1},{\text { Sylvain } \text { Triquet }^{1} \text {, and François Dulac }}^{2}$ \\ ${ }^{1}$ Laboratoire Interuniversitaire des Systèmes Atmopshériques (LISA), IPSL, UMR CNRS 7583, Université Paris-Est Créteil \\ et Université Paris-Diderot, Créteil, France \\ ${ }^{2}$ Laboratoire des Sciences du Climat et de l'Environnement (LSCE), UMR 8212 CEA-CNRS-UVSQ, IPSL, \\ Université Paris-Saclay, CEA Saclay 701, Gif-sur-Yvette, France
}

Correspondence: Karine Desboeufs (desboeufs@lisa.u-pec.fr)

Received: 31 January 2018 - Discussion started: 5 June 2018

Revised: 12 September 2018 - Accepted: 19 September 2018 - Published: 10 October 2018

\begin{abstract}
Total atmospheric deposition was collected on a weekly basis over 3.5 years (March 2008-October 2011) at a remote coastal site on the west coast of Corsica. Deposition time series of macro- and micronutrients (N, P, Si, Fe) and trace metals ( $\mathrm{As}, \mathrm{Cr}, \mathrm{Cu}, \mathrm{Mn}, \mathrm{Ni}, \mathrm{V}, \mathrm{Zn}$ ) are investigated in terms of variability and source apportionment (from fluxes of proxies for aerosol sources (Al, Ti, Ca, $\mathrm{Na}, \mathrm{Mg}, \mathrm{S}, \mathrm{Sr}, \mathrm{K}$, $\mathrm{Pb})$ ). The highest fluxes are recorded for $\mathrm{Si}, \mathrm{P}$, and $\mathrm{Fe}$ for nutrients and $\mathrm{Zn}$ and $\mathrm{Mn}$ for trace metals. For the majority of elements, data show some weeks with high episodic fluxes, except for $\mathrm{N}, \mathrm{Cr}$, and $\mathrm{V}$, which present the lowest variability. A total of 12 intense mineral dust deposition events are identified during the sampling period. The contribution of these events to the fluxes of $\mathrm{Fe}$ and $\mathrm{Si}$ represents $52 \%$ and $57 \%$ of their total fluxes, respectively, confirming the important role of these sporadic dust events in the inputs of these elements in the Mediterranean. For $\mathrm{N}$ and $\mathrm{P}$, the contribution of these intense dust deposition events is lower and reaches $10 \%$ and $15 \%$, respectively. Out of these most intense events, positive matrix factorization (PMF) was applied to our total deposition database in order to identify the main sources of nutrients and trace metals deposited. Results show that P deposition is mainly associated with anthropogenic biomass burning inputs. For $\mathrm{N}$ deposition, inputs associated with marine sources (maybe associated with the reaction of anthropogenic $\mathrm{N}$ on $\mathrm{NaCl}$ particles) and anthropogenic sources are quasi-similar. A good correlation is obtained between $\mathrm{N}$ and $\mathrm{S}$ fluxes, supporting a common origin associated with inorganic secondary aerosol, i.e., ammonium sulfate. For trace metals, their origin is very variable: with a large contribu-
\end{abstract}

tion of natural dust sources for $\mathrm{Ni}$ or Mn and conversely of anthropogenic sources for $\mathrm{V}$ and $\mathrm{Zn}$.

\section{Introduction}

The Mediterranean Sea is a semi-enclosed basin situated at the interface among contrasted continental areas of three continents, namely southern Europe, northern Africa, and the Middle East, the coastal areas of which are heavily populated. Thus, the Mediterranean Basin continuously receives anthropogenic aerosols from industrial and domestic activities from all around the basin and other parts of Europe (Sciare et al., 2008; Becagli et al., 2012). In addition to deposition from this anthropogenic background, seasonal inputs from biomass burning occur mainly during dry summers (Chester et al., 1996; Guieu et al., 1997), and strong deposition pulses of mineral dust from the Sahara are superimposed (Guerzoni et al., 1999a), with some extreme events with dust deposition fluxes as high as $22 \mathrm{~g} \mathrm{~m}^{-2}$ as recorded in 2004 (Bonnet and Guieu, 2006) on very short timescales of a few hours to a few days.

A number of key elements for marine biota are associated with those inputs. Thus, several authors showed that the atmospheric deposition of aerosols constitutes the main source of major nutrients, such as $\mathrm{N}, \mathrm{P}$, or Fe, to the surface open waters of the Mediterranean Sea in the summer-fall period when surface water stratification prevents inputs from deep water by vertical mixing (Guerzoni et al., 1999a; Bonnet and Guieu, 2006; Krom et al., 2010; Pulido-Villena et al., 2010; 
Richon et al., 2018a, Violaki et al., 2018). In addition to the classical nutrients $(\mathrm{N}, \mathrm{P}$, and $\mathrm{Fe})$, the aerosols also carry trace metals (hereafter called TMs) such as $\mathrm{Cr}, \mathrm{Cu}, \mathrm{Ni}, \mathrm{Mn}$, or $\mathrm{Zn}$ that are known to have a biological role, often as cofactors or part of cofactors, in enzymes and as structural elements in proteins (Morel and Price, 2003). The recent study of Ridame et al. (2011) suggests that the TMs released by Saharan dust could stimulate nitrogen fixation in summer in the Mediterranean Sea. This assumption is supported by the works of Tovar-Sánchez (2014), which show that the TM concentrations in the surface microlayer of the Mediterranean Sea are correlated with atmospheric deposition of mineral dust. However, it has also been suggested that the atmospheric deposition of particulate pollutants is responsible for the contamination of the Mediterranean waters in TMs (Bethoux et al., 1990; Guerzoni et al., 1999b). Gallisai et al. (2014) also show negative effects of dust deposition on chlorophyll, coinciding with regions under a large influence of aerosols from European origin.

Thus, the partitioning/mixing between anthropogenic and natural atmospheric inputs is critical to estimate and predict the role of the atmospheric deposition in the marine biosphere and associated services (Richon et al., 2018b). However, in the Mediterranean Sea, the existing database on atmospheric fluxes of nutrients and TMs remains quite limited. Most studies are focused on total deposition of dust and/or macronutrients such as P and N (e.g., Markaki et al., 2010). This approach does not include the variety of nutrients and does not enable one to distinguish the origin of nutrientbearing particles. Moreover, the studies on TM deposition $(\mathrm{Cd}, \mathrm{Pb}$, etc.) often show an influence of local sources (Guieu et al., 2010), limiting the reliability of these data. Unlike atmospheric deposition, the source apportionment of suspended particles over the Mediterranean, from the positive matrix factorization (PMF) method, has been highly investigated in recent works and showed a large spatial variability in source contributions (Becagli et al., 2012, 2017; Calzolai et al., 2015; Amato et al., 2016; Diapouli et al., 2017). The signature of continental pollution sources was observed even in remote areas such as central Mediterranean islands (Calzolai et al., 2015). Yet, PM concentrations and sources are probably different than sources of deposited particles, which depend on aerosol size distribution and precipitation patterns, among other factors. Thus, in a context of anthropogenic changes, it is crucial to distinguish between anthropogenic and natural atmospheric inputs of nutrients in order to assess how the evolution of chemical atmospheric forcing will modify the marine nutrient cycling.

Here we show a 3.5-year-long continuous series of total deposition fluxes of macro- and micronutrients ( $\mathrm{N}, \mathrm{P}, \mathrm{Si}, \mathrm{Fe})$, TMs (As, Cr, Cu, Mn, Ni, V, Zn), and source tracers (Al, Ti, $\mathrm{Ca}, \mathrm{Na}, \mathrm{Mg}, \mathrm{S}, \mathrm{Sr}, \mathrm{K}, \mathrm{Pb}$ ) at a remote coastal site in Corsica. Between March 2008 and October 2011, a monitoring station was operated with a weekly sampling time step for total bulk deposition. In order to assess the contribution of sources in the fluxes of nutrients, work on the source apportionment of various nutrients and TMs was carried out from these data (PMF method). Specific attention was also given to the different types of extreme atmospheric events that are relevant regarding the biogeochemistry in the Mediterranean Sea. They include Saharan events and intense summer storms that trigger the washout of the atmosphere over an altitude of several thousands of meters in a short time.

\section{Material and methods}

\subsection{Sampling site and protocol}

Total bulk deposition (i.e., dry + wet deposition) was sampled weekly from March 2008 to October 2011 using an open collector for nutrients and TM analyses, except for N, for which the analyses started only from November 2009. Sampling was conducted at Cap Cuittone $\left(42.44^{\circ} \mathrm{N}, 8.66^{\circ} \mathrm{E}\right.$, $190 \mathrm{~m}$ above sea level). The sampling site is on the Mediterranean coast of the Corsica National Park (Parc Naturel Régional de Corse) at $16 \mathrm{~km}$ to the SSE of Calvi, the main city on that part of the island, which has no important industry ( $~ 5500$ inhabitants), and about $3.5 \mathrm{~km} \mathrm{~N}$ of the village of Galéria ( 350 inhabitants). Consequently, the data from this site could be considered representative of the open western Mediterranean Sea.

The sampler is a $120 \mathrm{~mm}$ diameter PTFE Teflon ${ }^{\circledR}$ funnel (collection aperture $0.0113 \mathrm{~m}^{2}$ ) machined on a circular base with a thread adapted to a $500 \mathrm{~mL}$ polypropylene (PP) Nalgene ${ }^{\circledR}$ bottle neck. The funnel stem is a long tapered stem so that it soaks in the preloaded acid for limiting the evaporation of collected water. All the deposition sampling materials (Teflon ${ }^{\circledR}$ PTFE capped funnels, 500 and $60 \mathrm{~mL}$ Nalgene ${ }^{\circledR}$ PP bottles, and $60 \mathrm{~mL}$ PP boxes with a screwing cap for the bottle's corks) were thoroughly washed with hydrochloric acid at the ultraclean laboratory of LISA following a protocol adapted for ultraclean sampling (Heimburger et al., 2012). Before deployment, the sampling bottles are preloaded with $50 \mathrm{~mL}$ of hydrochloric acid $(2 \% v / v)$ and weighed. Each funnel coupled to its preloaded bottle was deployed on the site at $2 \mathrm{~m}$ in height. The position was controlled by a spirit level to ensure that the funnel aperture was horizontally leveled. Each week, before collection, the internal surface of the funnel was rinsed with $60 \mathrm{~mL}$ of $2 \% \mathrm{v} / \mathrm{v}$ ultrapure hydrochloric acid in ultrapure water, taking care to flush the entire surface. The rinsing solution was collected in the sample bottle to be removed and replaced by a new $500 \mathrm{~mL}$ PP bottle for the next week. The funnel was replaced by a new one every 6 months. Field blanks were performed at funnel installation and removal, but also from time to time by repeating the sampling procedure twice. One permanent staff member of the Corsica National Park was carefully advised and performed sampling during the entire monitoring period. 


\subsection{Chemical analyses}

In the laboratory, bottles sampling total atmospheric deposition were weighted. The amount of rainwater collected in the funnel was deduced by subtracting added acid solution (i.e., $110 \mathrm{~mL}$ ) from the sample total mass found in the bottle. Each sample was shaken and then $15 \mathrm{~mL}$ was immediately transferred into a PE sampling vial to measure the size distribution of the particulate phase (not discussed here). The rest of the sample was filtered before analysis with acidwashed Nuclepore ${ }^{\circledR}$ polycarbonate filters $(0.2 \mu \mathrm{m}$ porosity). The filters were analyzed by wavelength dispersive X-ray fluorescence (PW-2404 spectrometer by PANalytical ${ }^{\mathrm{TM}}$ ) for the particulate elemental concentrations for elements from $\mathrm{Na}$ to $\mathrm{Pb}$, including macro- $(\mathrm{P})$ and micronutrients $(\mathrm{Fe}, \mathrm{Si})$, TMs (As, $\mathrm{Cr}, \mathrm{Cu}, \mathrm{Mn}, \mathrm{Ni}, \mathrm{V}, \mathrm{Zn}$ ), and source tracers ( $\mathrm{Al}$, Ti, $\mathrm{Ca}, \mathrm{Na}, \mathrm{Mg}, \mathrm{S}, \mathrm{Sr}, \mathrm{K}, \mathrm{Pb}$ ). Analyses of the filtered aqueous sample were performed with inductively coupled plasmaatomic emission spectrometry (ICP-AES, Spectro ARCOS Ametek $^{\circledR}$ ) coupled with a CETAC ultrasonic nebulizer for dissolved elemental concentrations of as many TMs as possible (altogether 45 elements were analyzed; Desboeufs et al., 2014). Due to the time between collection and analyses, the preservation of $\mathrm{N}$ speciation was not guaranteed and in consequence data are expressed as total $\mathrm{N}$. The total dissolved inorganic $\mathrm{N}$ concentrations were obtained by adding $\mathrm{NH}_{4}^{+}$concentrations and $\mathrm{NO}_{3}^{-}$and $\mathrm{NO}_{2}^{-}$concentrations determined by ionic chromatography (850 Professional IC by Metrohm ${ }^{\mathrm{TM}}$ ). Field blank concentrations are significantly inferior to sample concentrations for all the studied elements. They represent on average from $1.4 \% \pm 1.3 \%(\mathrm{Mn})$ to $12 \% \pm 6 \%(\mathrm{Fe})$ of studied element concentrations, with a maximum contribution of $19 \%$ for TMs (V) and $22 \%$ for major nutrients (Fe). Field blank concentrations are subtracted from sample concentrations collected in the same period.

The weekly elemental deposition fluxes were calculated from concentrations of all chemical species measured in dissolved and particulate samples by considering the sampler area and the total liquid volume (preloading + rinsing + rain). The total elemental deposition fluxes were estimated by adding particulate and dissolved fluxes, except for $\mathrm{N}$, which was assumed to be totally acid soluble. Atmospheric nitrogen exists in the particulate phase but also as a gaseous species $\left(\mathrm{NO}_{x}, \mathrm{HNO}_{3}, \mathrm{NH}_{3}\right)$. In our study, the used bulk collector has a design very close to the one of bulk collectors used during the ADIOS project, which are not optimized to collect gaseous nitrogen by dry deposition (Markaki et al., 2008). However, wet deposition included both washed-out particulate and gaseous nitrogen, and measured $\mathrm{N}$ fluxes in this study will be considered mainly representative of bulk deposition of aerosol particles plus wet deposition of gaseous $\mathrm{N}$.

\subsection{Dry vs. wet deposition}

The speciation between wet and dry deposition is a critical parameter to estimate the potential dissolved fluxes of nutrients. Precipitation $(\mathrm{mm})$ was estimated at the site from the amount of water in the sample. The precipitation occurrences are in agreement with the rainfall records at Calvi airport, which is about $15 \mathrm{~km}$ away. Since they are more representative of local rainfall, precipitation estimated from our samples was used for the attribution of deposition fluxes to wet vs. dry deposition. Wet deposition was considered when rainfall was larger than $1 \mathrm{~mm}$ during the sampling period. The threshold value of $1 \mathrm{~mm}$ integrates the uncertainties on the weighing of samples in order to ascertain that the rainfall was real. Samples that present no precipitation or rainfall lower than $1 \mathrm{~mm}$ are considered dry deposition. In consequence, dry deposition is assimilated into wet deposition when happening the same week as a precipitation event. This method underestimates dry deposition and provides a lower estimate of deposition dry event number vs. total deposition event number.

\subsection{Positive matrix factorization (PMF)}

Multivariate statistical methods, such as factor analysis, are widely used to identify source signatures and explore sourcereceptor relationships using the trace element compositions of atmospheric aerosols (e.g., Polissar et al., 2001; Calzolai et al., 2015) and precipitation (Keeler et al., 2006; Gratz et al., 2013). Since many sources emit characteristic relative amounts of certain trace elements, source-receptor techniques can be used with an understanding of these elemental signatures to identify the major sources influencing a given receptor site.

We applied EPA PMF v5.0 (Norris et al., 2014) to the matrices of tracers, nutrients, and TM total deposition measurements. PMF is a multivariate statistical technique that uses weighted least-squares factor analysis to decouple the matrix of observed values $(\mathbf{X})$ into two matrices representing the factor scores $(\mathbf{G})$ and factor loadings $(\mathbf{F})$, as represented by the equation $\mathbf{X}=\mathbf{G F}+\mathbf{E}$, where $\mathbf{E}$ is the residual matrix representing the difference between observed and predicted values (Paatero and Tapper, 1994; Paatero, 1997). Prior to applying PMF, we used the weekly deposition fluxes and we replaced fluxes reported as less than the median detection limit (MDL) with the median value. The uncertainties for each sample correspond to the sum of uncertainties in sample collection (i.e., 10\%) and analytical measurement (standard deviation of three replicate analyses for each sample). We included all valid samples, excluding the samples that we identified as extreme outliers, i.e., samples corresponding to dust events and high As deposition (12 samples) (see Sect. 3.4). The deposition fluxes for 21 elements are used, i.e macro- and micronutrients (N, P, Si, Fe), TMs (As, $\mathrm{Cr}, \mathrm{Cu}$, $\mathrm{Mn}, \mathrm{Ni}, \mathrm{V}, \mathrm{Zn}$ ), and tracer elements (Al, Ti, $\mathrm{Ca}, \mathrm{Na}, \mathrm{Mg}$, sea 
salt $\mathrm{S}$ (Sss), $\mathrm{Pb}, \mathrm{K}$, and excess $\mathrm{S}$ (Sexc)). The estimation of Sss fluxes is obtained from $\mathrm{Na}$ fluxes on the basis of typical seawater S/Na ratios (Henderson and Henderson, 2009) and Sexc fluxes in subtracting Sss from total S fluxes. Since S was used as a source tracers, the discrimination between Sss and Sexc enabled us to have the best constraint on the signature of sources. Elements with a signal-to-noise $(S / N)$ ratio $<5$ were categorized as "weak" (i.e., As and N) and hence downweighted so that the user-provided uncertainty was increased by a factor of 3 (Norris et al., 2014). The variability in the PMF solution was estimated using a block bootstrap technique, which calculates the stability of the model solution by randomly resampling blocks of the input dataset and computing the variability among model solutions. We applied 100 bootstrap runs to the PMF base run with the lowest $Q$ value. We determined the final factor profiles based on our ability to identify all the factors, the robustness of $Q$ values, the ability of the model to replicate measured results, and the bootstrap results.

\section{Results and discussion}

The 3.5-year time series of weekly fluxes (195 samples) for nutrients, TMs, major source tracer elements ( $\mathrm{Al}, \mathrm{Na}, \mathrm{S}$, and $\mathrm{K})$, and precipitation are presented in Fig. 1. Corresponding time series of other source tracer elements $(\mathrm{Ti}, \mathrm{Mg}, \mathrm{Sr}, \mathrm{Pb}$ ) are available in the Supplement with the total atmospheric flux data. The highest fluxes are recorded for $\mathrm{Si}, \mathrm{P}$, and $\mathrm{Fe}$ for major nutrients and $\mathrm{Zn}$ and Mn for TMs. A total of $51 \%$ of the samples, i.e., 99 samples, sustained at least one event of precipitation during the week of sampling and are here referenced as wet deposition. In our set of 195 samples, 21 presented a rainfall higher than $20 \mathrm{~mm}$ and the highest weekly rainfall recorded is $29 \mathrm{~mm}$. However, no systematic link is observed between the biggest rain event and the nutrients or metal fluxes.

The results emphasize large differences in timing of deposition fluxes among the studied elements. But for all the elements, the data display some weeks with high episodic fluxes. Due to the sporadic character of specific events such as dust storms or forest fires, giving rise to high-deposition events, it is known that the fluxes of elements associated with these sources are often important in a short period. For example, for elements such as aluminium associated with dust events, a half or more of the annual deposition flux may occur in one event of a few days or even hours (Guieu et al., 2010), and high-deposition events $\left(>1 \mathrm{~g} \mathrm{~m}^{-2}\right)$ are responsible for the interannual variability in the $\mathrm{Al}$ deposition flux in the western Mediterranean Basin (Löye-Pilot and Martin, 1996). As a consequence, the fluxes linked to these extreme events can dominate and hide the influence of more continuous emission sources. In our dataset, this is the case for $\mathrm{Si}$, $\mathrm{Fe}$, and As, for which $25 \%$ of total fluxes in 3.5 years are delivered by one to three weekly samples, whereas for the majority of nutrients and TMs, $25 \%$ of total fluxes are constituted from the five to eight highest events. The most obvious case is for As, which $23 \%$ of the total flux is obtained in only 1 week during June $2010\left(0.1 \mathrm{mg} \mathrm{m}^{-2}\right.$ week $\left.^{-1}\right)$. This event corresponds to one event of wet deposition of $7 \mathrm{~mm}$, i.e., no particularly intense rain, and is concomitant with high fluxes for the other studied elements.

\subsection{Seasonal variability}

Monthly total and wet fluxes have been estimated to investigate the seasonal variability in the measured elements' inputs over the northwestern Mediterranean (Fig. 2). A large variability in the monthly deposition fluxes of all the elements is observed in agreement with the episodic pattern of weekly inputs. Nutrient deposition presents a clear seasonal pattern: $\mathrm{P}$ has major deposition fluxes in summer and $\mathrm{N}$ in winter, whereas the main fluxes are observed in spring for $\mathrm{Fe}, \mathrm{Si}, \mathrm{Cr}$, $\mathrm{Ni}$, and V. For As, excluding June, which shows its highest monthly mean flux due to the intense event of June 2010, the maximum of fluxes is recorded at the end of summer and beginning of fall. For Mn, no clear seasonality is observed. A monthly flux predominates in August and November for $\mathrm{Zn}$ and $\mathrm{Cu}$, respectively, reaching at least twice the other monthly fluxes. For all the elements, the wet deposition predominates the total fluxes between October and April in agreement with the highest rainfall recording during this period, whereas dry deposition is the main path of input in May, July, and August. Our results are in agreement with the seasonal pattern observed in the 1980s for $\mathrm{Si}$ and Fe deposition at Capo Cavallo, $8 \mathrm{~km}$ further north on the Corsican coast (Bergametti et al., 1989). The maximum of deposition during spring is explained by the concomitance of rainfall and high dust concentrations, whereas $\mathrm{Si}$ and $\mathrm{Fe}$ atmospheric aerosol concentrations present their maximum in summer during the dry season. This emphasizes that the below-cloud scavenging of aerosol is the predominant process explaining atmospheric deposition of dust-related elements in this period. For the elements mainly associated with dry deposition, i.e., Zn, P, and Cr, Bergametti et al. $(1989,1992)$ observed that the highest deposition was typically associated with the period of their highest aerosol concentrations in summer. This is not the case for $\mathrm{Cr}$ in our results, which follows the $\mathrm{Si}$ and $\mathrm{Fe}$ behavior. Unlike our Corsica site, no clear seasonal variability is observed for the deposition fluxes recorded at Cap Ferrat, $170 \mathrm{~km}$ further NNE on the French continental coast, a site affected by the anthropogenic influences from continental Europe (Pasqueron de Fommervault et al., 2015). That could be the case for Mn atmospheric fluxes at our site.

The case of $\mathrm{N}$ deposition is specific since the $\mathrm{N}$ deposition flux corresponds mainly to total aerosol and wet gaseous deposition inputs in our samples. The general pattern for $\mathrm{N}$ with the highest fluxes in winter could be linked to the thermal instability of ammonium nitrate, which is the dominant form of $\mathrm{N}$ in aerosol particles associated with a decrease in rain 


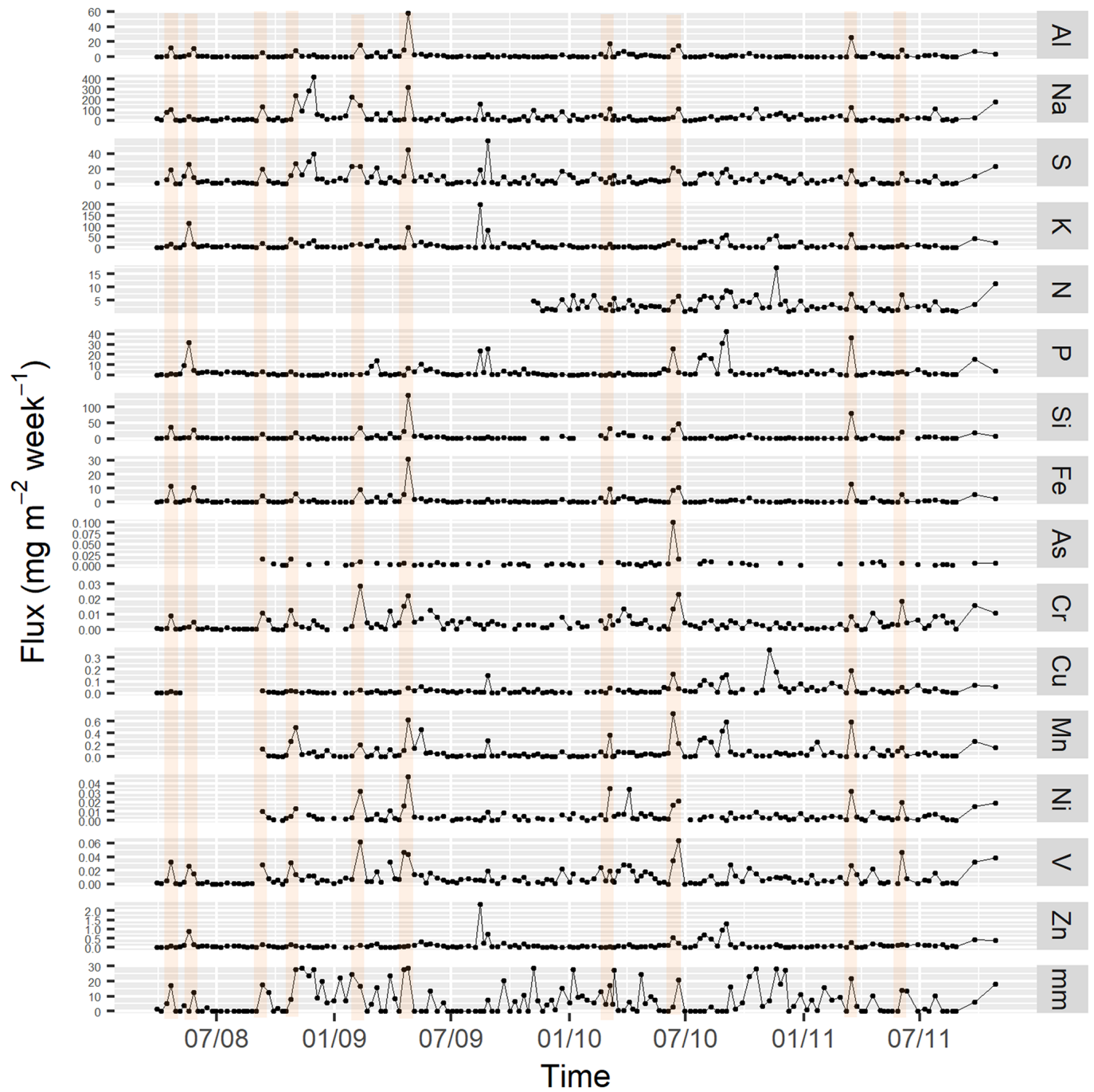

Figure 1. Temporal variability in bulk weekly fluxes from March 2008 to October 2011 for main markers, nutrients, and trace metals and rainfall during the same period. The 10 most intense dust events are displayed in the boxes in orange (see details in Sect. 3.4).

events during the hot season and with extremely typical intense nitrate episodes recorded from November to March in the western Mediterranean Basin associated with maximum wet deposition (Querol et al., 2009). The highest N deposition flux is recorded in November 2010 (Fig. 1); this event is associated with wet deposition and is coincident with a deposition peak for $\mathrm{Cu}$ and $\mathrm{K}$.

\subsection{Interannual variability}

The average annual total deposition fluxes for the major nutrients and TMs during the 3.5 years of sampling are presented in Table 1. Among major nutrients, the most abundant nutrients in bulk deposition are $\mathrm{Si}$ followed by $\mathrm{P}$ and $\mathrm{N}$, which have fluxes of the same order of magnitude. The highest annual fluxes recorded for $\mathrm{N}$ in comparison to $\mathrm{Fe}$ are due to the sporadic pattern of Fe fluxes in comparison to $\mathrm{N}$ that shows more regular weekly fluxes. For TMs, the highest annual fluxes are observed for $\mathrm{Zn}, \mathrm{Mn}$, and $\mathrm{Cu}$, whereas the other TMs have fluxes smaller by 1 order of magnitude. Except for $\mathrm{Ni}$, the standard deviations on the mean fluxes are larger than $15 \%$ and reach more than $50 \%$ for $\mathrm{P}, \mathrm{As}$, and $\mathrm{Cu}$, meaning a large interannual variability in their deposition, in agreement with the high recorded sporadic weekly fluxes for these elements. Our results are compared with other fluxes in Corsica (Table 1) as reported in the literature. Data show that for TMs, the recorded values are of the same order of magnitude as previous measurements in Corsica. Conversely, for the major elements $\mathrm{Fe}, \mathrm{Si}$, and $\mathrm{N}$, except for $\mathrm{P}$, our deposition flux values are much lower than the previous ones obtained in Corsica (Table 1) and globally in the western Mediterranean (Bonnet and Guieu, 2006; Pasqueron de Fommervault et al., 2015). A net decrease in $\mathrm{N}$ deposition is also observed be- 

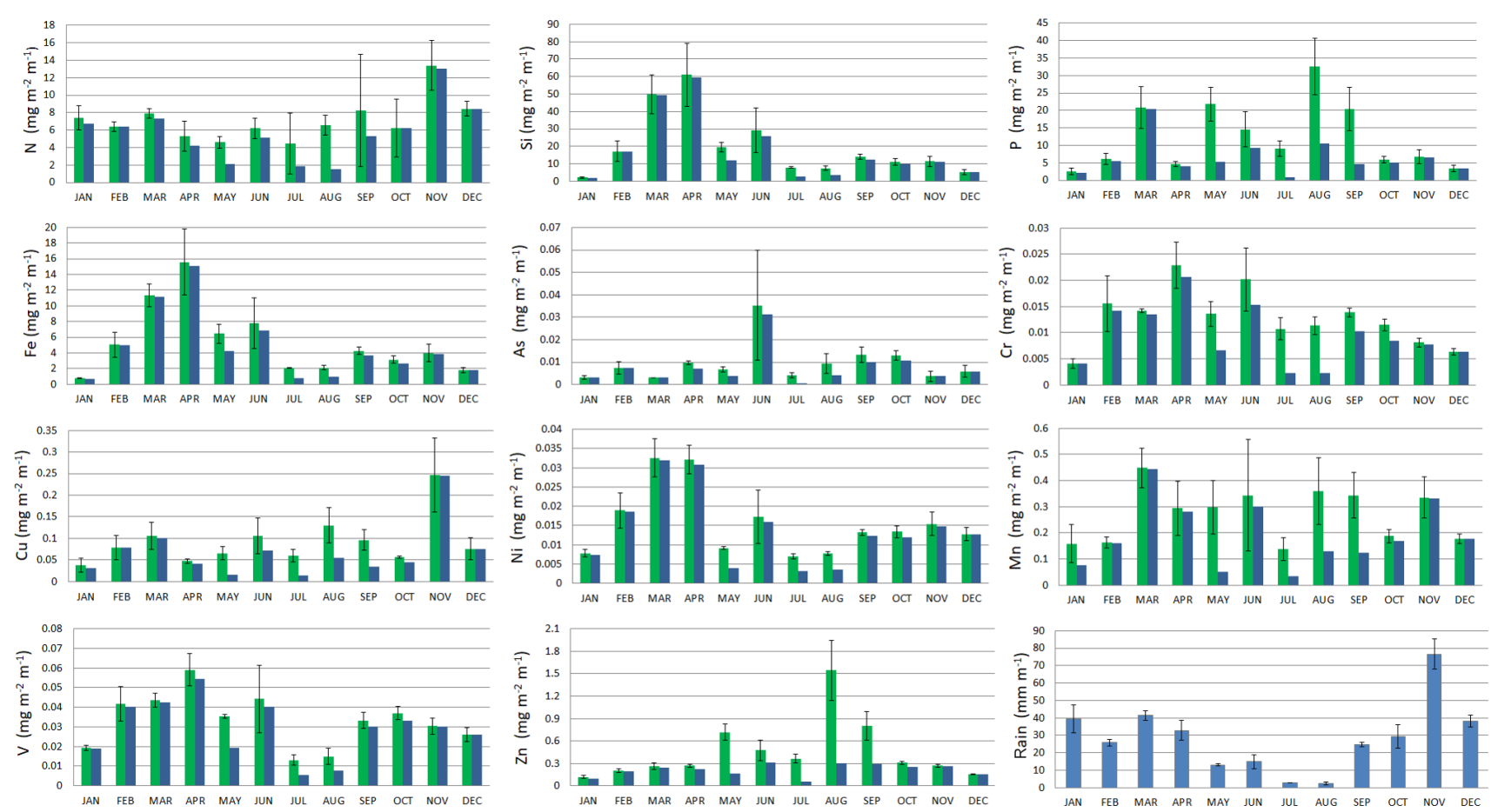

Figure 2. Temporal variation in monthly total (green bars) and wet (blue bars) deposition and precipitation during the sampling period March 2008-October 2011. Bars indicate standard deviations over the weekly values available over the period.

tween the 1990s and now in Europe (Waldner et al., 2014). The only element with the highest deposition fluxes in comparison to the literature is $P$, suggesting an increase in atmospheric fluxes for this element. Keeping in mind that dry deposition events can be underestimated by our method, the wet fluxes predominate the total deposition fluxes $(\geq 64 \%)$ for the majority of elements except for $\mathrm{P}$ and $\mathrm{Zn}$, for which less than half of the total flux is associated with precipitation. This is in agreement with the seasonality of deposition of these elements, which is high in summer when the contribution of dry deposition is the highest.

\subsection{Mineral dust deposition fluxes}

The annual deposition fluxes of soil dust have been estimated from $\mathrm{Al}$ fluxes, considering an amount of $\mathrm{Al}$ of $7 \%$ (Guieu et al., 2010). The results show that the mean annual dust flux ranges from 1.39 to $1.94 \mathrm{~g} \mathrm{~m}^{-2} \mathrm{yr}^{-1}$. Typically, $70 \%$ of the annual flux is related to three or four dust deposition events during the year, in agreement with the sporadic pattern of dust input over the year (Löye-Pilot and Martin, 1996). For example, a weekly maximum of $0.82 \mathrm{~g} \mathrm{~m}^{-2} \mathrm{w}^{-1}$ is recorded during the last week of April 2009, representing $44 \%$ of the total flux for this year. It is well known that intense dust events lead to a very high intra- and interannual variability. Al deposition data recorded in Corsica show a range of dust fluctuation for the period 1985-2002 in Corsica of 4 to $28 \mathrm{~g} \mathrm{~m}^{-2} \mathrm{yr}^{-1}$ (Guieu et al., 2010), a higher value always being associated with very intense events $\left(>10 \mathrm{~g} \mathrm{~m}^{-2}\right)$. Our values between 2008 and 2011 are lower than the range previously measured between the 1980 s and early 2000 s, probably because no intense dust event $\left(>1 \mathrm{~g} \mathrm{~m}^{-2}\right)$ was recorded during the sampling period (Fig. 3). This trend is consistent with the low annual deposition mass fluxes observed by Vincent et al. (2016) recorded in Corsica and more generally in the western Mediterranean between 2011 and 2013 $\left(\max 2.1 \mathrm{~g} \mathrm{~m}^{-2} \mathrm{yr}^{-1}\right)$. This result is also coherent with the decreasing trend in $\mathrm{PM}_{10}$ concentrations over the Mediterranean region due to the decrease in dust contribution (Pey et al., 2013). As mentioned by Moulin et al. (1997) and Pey et al. (2013), this is probably due to the variation in large-scale atmospheric circulation affecting dust atmospheric contents (lower values of the North Atlantic Oscillation indices during the last 2 decades). This trend could also be related to the low dust activity period in the Sahara during the 2000s in comparison to 1970-1990 proposed by Evan et al. (2016) from wind variability patterns. However, with the kind of deposition collectors and the sampling sites being different, we cannot exclude effects of sampling conditions on the obtained results.

\subsection{The case with high-deposition events}

Over our sampling period (March 2008-October 2011), the average weekly dust deposition is $0.028 \pm 0.07 \mathrm{~g} \mathrm{~m}^{-2} \mathrm{w}^{-1}$. In order to identify the outlier dust events in the dataset, 
Table 1. The left part shows the annual total and wet and dry deposition fluxes $\left(\mathrm{mg} \mathrm{m}^{-2} \mathrm{yr}^{-1}\right)$ of major nutrients and trace elements and the relative contribution (\%) of wet periods to the total fluxes measured at Capo Cuittone, Corsica, between March 2008 and October 2011. The right part shows annual deposition fluxes at various sites in Corsica available in the literature.

\begin{tabular}{|c|c|c|c|c|c|c|c|c|c|}
\hline \multirow[t]{2}{*}{ Element } & \multicolumn{2}{|c|}{ Total flux } & \multirow{2}{*}{$\begin{array}{l}\text { Wet flux } \\
\text { Average }\end{array}$} & \multicolumn{2}{|l|}{ Dry flux } & \multirow{2}{*}{$\begin{array}{r}\text { Capo Cavallo }^{\mathrm{a}} \\
\text { Feb } 1985 \text { to } \\
\text { Nov } 1987\end{array}$} & \multirow{2}{*}{$\begin{array}{r}\text { Pirio }^{\text {b }} \\
\text { Jan } 1995 \text { to } \\
\text { Mar } 1997\end{array}$} & \multirow{2}{*}{$\begin{array}{r}\text { Ostrioni }^{\mathrm{c}} \\
\text { Jun } 2001 \text { to } \\
\text { May } 2002\end{array}$} & \multirow{2}{*}{$\frac{\text { Bavella }}{1984-1986}$} \\
\hline & Average & Range & & Average & $\%$ wet & & & & \\
\hline $\mathrm{N}$ & $143 \pm 61$ & $81-167$ & 107.6 & 19.9 & $84 \%$ & & & $355-377^{\mathrm{e}}$ & $644-766$ \\
\hline $\mathrm{P}$ & $149 \pm 79$ & $114-253$ & 73.3 & 75.4 & $49 \%$ & $24.2-40.1$ & & 43.2 & \\
\hline FE & $67 \pm 10$ & $65-77$ & 56.2 & 10.5 & $84 \%$ & 395-406 & $118-156$ & 1188 & \\
\hline SI & $246 \pm 61$ & 197-280 & 206.7 & 39.3 & $84 \%$ & & & & \\
\hline AS & $0.14 \pm 0.07$ & $0.10-0.20$ & 0.10 & 0.06 & $64 \%$ & & & & \\
\hline CR & $0.16 \pm 0.04$ & $0.12-0.19$ & 0.11 & 0.05 & $69 \%$ & & & & \\
\hline $\mathrm{CU}$ & $1.06 \pm 1.07$ & $0.44-2.16$ & 0.72 & 0.33 & $68 \%$ & $2.3-3.7$ & $0.7-1.4$ & & \\
\hline $\mathrm{MN}$ & $3.7 \pm 1.4$ & $2.5-5.2$ & 2.15 & 1.20 & $64 \%$ & $12.5-15.2$ & $6.3-6.5$ & & \\
\hline NI & $0.21 \pm 0.01$ & $0.14-0.24$ & 0.16 & 0.03 & $84 \%$ & & 0.4 & & \\
\hline V & $0.4 \pm 0.06$ & $0.34-0.46$ & 0.33 & 0.07 & $83 \%$ & & & & \\
\hline $\mathrm{ZN}$ & $5.7 \pm 1.9$ & $3.74-7.42$ & 2.51 & 3.20 & $44 \%$ & & $4.2-6.1$ & 6 & \\
\hline
\end{tabular}

a Total bulk deposition from Bergametti et al. (1987, 1992) and Remoudaki et al. (1991). ${ }^{\text {b }}$ Total bulk deposition from Ridame et al. (1999).

${ }^{c}$ Total bulk deposition from Guieu et al. (2010) and Markaki et al. (2010). ${ }^{\mathrm{d}}$ Total wet deposition from Löye-Pilot et al. (1990). ${ }^{\mathrm{e}}$ Data obtained between June 2001 and May 2003.

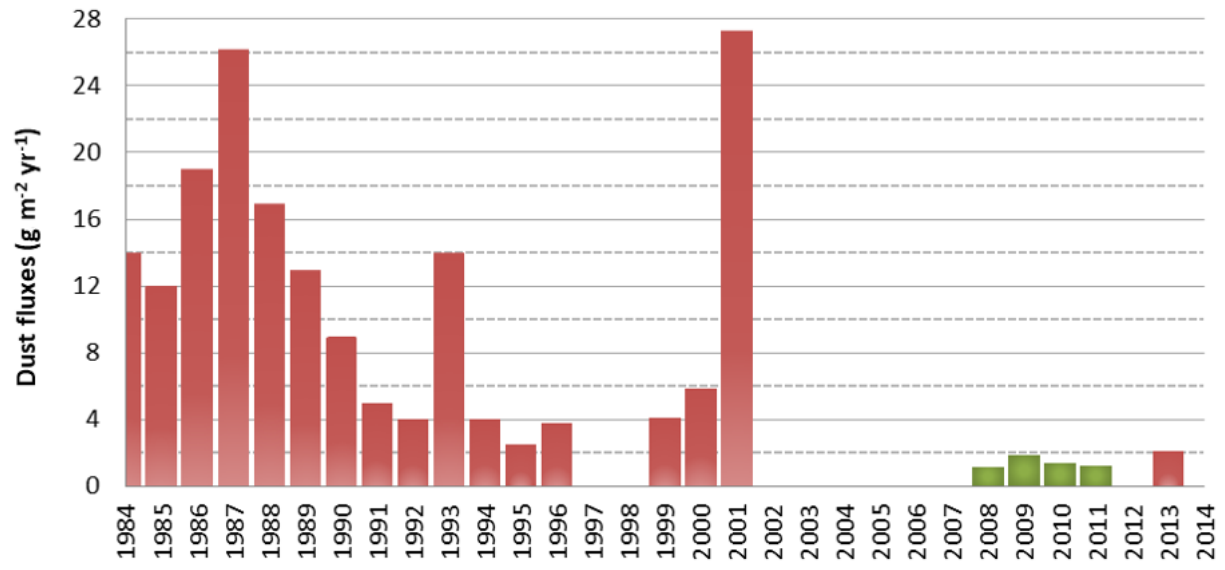

Figure 3. Time series of dust fluxes $\left(\mathrm{g} \mathrm{m}^{-2} \mathrm{yr}^{-1}\right)$ at various locations in Corsica issued from Löye-Pilot and Martin (1996) for years between 1984 and 1994, from Ridame et al. (1999) for 1995 and 1996, from Guieu et al. (2010) for 2001-2002, from Vincent et al. (2016) for 2013 (all in red), and from this work for 2008-2011 (in green).

we selected the samples with weekly fluxes higher than the last 95th percentile of data, i.e., the highest $5 \%$ of values. Thus, weekly dust fluxes $>0.104 \mathrm{~g} \mathrm{~m}^{-2} \mathrm{w}^{-1}$ are considered to be extreme dust events. From this threshold, 12 samples are isolated and correspond to 10 dust events (two events concern two successive sampling periods in April 2009 and June 2010). All these events correspond to wet deposition periods (Fig. 1). Observations of remote-sensing data from MODIS or SEVIRI confirm that these events are due to intense Saharan dust plumes associated with clouds (not shown). Eight of these events happened in spring (between March and June), one in fall and one in winter, in agreement with the seasonal pattern of dust plumes over the western
Mediterranean (Moulin et al., 1998) and in particular in Corsica (Bergametti et al., 1989; Salvador et al., 2014). The first week of one of the two dust events that fall in two sampling periods also corresponds with the episode of high As deposition $\left(0.1 \mathrm{mg} \mathrm{m}^{-2} \mathrm{wk}^{-1}\right)$ recorded in June 2010 . This weekly As flux represents the annual flux measured in a remote environment like a Scandinavian forest $\left(0.1 \mathrm{mg} \mathrm{m}^{-2} \mathrm{yr}^{-1}\right.$ on average between 2002 and 2005; Hovmand et al., 2008). It is much larger than the weekly fluxes recorded in an urban environment such as Venice where the reported fluxes range from 0.7 to $367 \mu \mathrm{g} \mathrm{m}^{-2} \mathrm{wk}^{-1}$ between 2005 and 2010 (Morabito et al., 2014). The As/Al ratio (0.011) for this event shows a large enrichment in As $(\times 16)$ in comparison to the average 
of other intense dust events $\left(7.10^{-4}\right)$, which is in agreement with the crustal ratio (Mason and Moore, 1982). The identified sources of atmospheric particulate As are coal-fired industries, waste incineration, oil refining, mining, and fossil fuel combustion (Wai et al., 2016). In the given sample, an enrichment in comparison to the other intense dust events is also observed for $\mathrm{P}(\times 12), \mathrm{Sr}(\times 9)$, and $\mathrm{Cu}$ and $\mathrm{Zn}(\times 6)$, whereas no significant enrichment is observed during the second sampling week of the dust event. In addition to dust and marine aerosol, biomass burning and fossil fuel combustion are the main sources of anthropogenic $\mathrm{Cu}, \mathrm{P}, \mathrm{Sr}$, and $\mathrm{Zn}$ (Mahowald et al., 2008; Nava et al., 2015). Moreover, the particulate filter corresponding with this event was brown-grey, showing a probable mixing between dust and black carbon (not shown). During the As-rich deposition week, the back trajectories show that the air masses came mainly from the south in concomitance with a high dust intrusion in the western Mediterranean Basin (Fig. 4); no intense biomass burning event is recorded during this period for the pathways of back trajectories. A mixing with dust and anthropogenic aerosol, rich in metals, over the Mediterranean has already been observed (Dulac et al., 1987; Heimburger et al., 2016). Our observations suggest that either deposition from a likely local combustion source occurred during the week of the dust deposition event or the deposited dust was mixed with aerosols issued from a combustion source along its transport over Africa or the Mediterranean.

The dust flux associated with these most intense dust deposition events represents $56 \%$ of the total dust flux in the 3.5 years of recording. The contribution of dust events to the fluxes of $\mathrm{Fe}$ and $\mathrm{Si}$ represents $52 \%$ and $57 \%$ of their total fluxes, respectively. Our results confirm the important role of these sporadic dust events in the inputs of these elements. In agreement with previous observations, $\mathrm{Si}$ and Fe fluxes also present a good correlation with Al fluxes $\left(R^{2}=0.97\right.$ and 0.96 , respectively) and mean mass ratios $(\mathrm{Si} / \mathrm{Al}=2.5$ and $\mathrm{Fe} / \mathrm{Al}=0.57$ ) are typical of Saharan dust (Formenti et al., 2008, 2011) and of transported dust at European sites (Alastuey et al., 2016), supporting more generally the important role of dust deposition in $\mathrm{Si}$ and $\mathrm{Fe}$.

For $\mathrm{N}$ and $\mathrm{P}$, the contribution of the outlier dust events is lower and reaches $10 \%$ and $15 \%$, respectively, and even $11 \%$ for $\mathrm{P}$ if the As-dust mixed event is excluded. That means that sources other than soil dust dominate the fallouts of these species (Fig. 1). However, a peak in $\mathrm{N}$ and $\mathrm{P}$ fluxes is systematically observed during high dust events, showing at the same time that intense dust deposition is also a source of these elements. The reactivity between dust and nitric acid previously observed in the Mediterranean (e.g., Puteaud et al., 2004) could explain the link between dust fluxes and $\mathrm{N}$ fluxes. For TMs, the high-dust-deposition events represent around $1 / 3$ of total fluxes for $\mathrm{Cr}, \mathrm{Mn}, \mathrm{Ni}$, and $\mathrm{V}$, whereas the contribution is low for As (10\% without the intense event), $\mathrm{Cu}$ ( $16 \%$ and even $12 \%$ excluding the As-dust mixed event), and $\mathrm{Zn}(9 \%$ and even $6 \%$ excluding the As-dust mixed
NOAA HYSPLIT MODEL

(a) Backward trajectories ending at 12:00 UTC 14 Jun 10 GDAS meteorological data

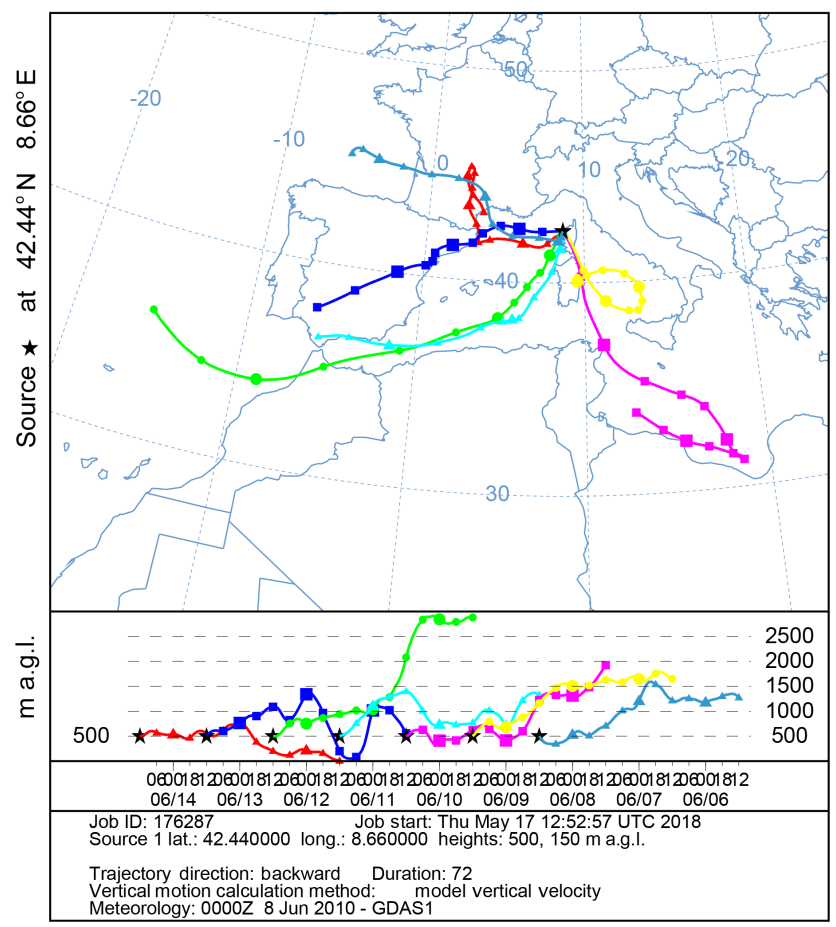

(b)

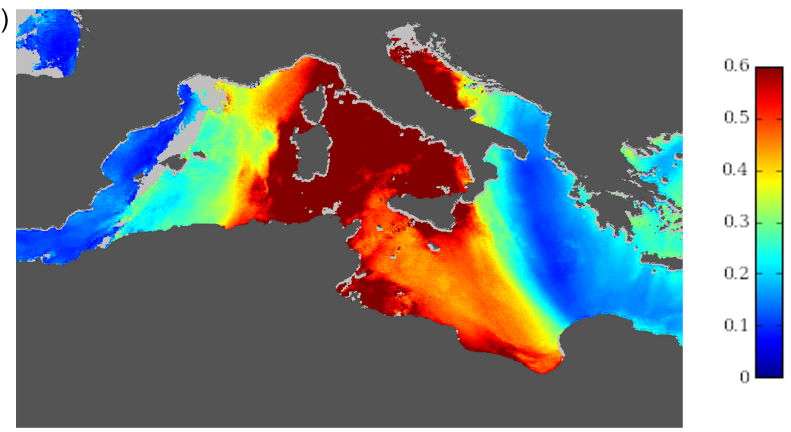

Figure 4. (a) Pathways of 3-day back trajectories ending at $500 \mathrm{~m}$ at the sampling site at noon from the NOAA HYSPLIT model for the week of the As-rich event and (b) MSG/SEVIRI daily (daytime) mean aerosol optical depth over the ocean for 10 June 2010 in agreement with the intrusion of an intense Saharan dust event during this week.

event). Keeping in mind that no high-dust-deposition event $>1 \mathrm{~g} \mathrm{~m}^{-2}$ has been recorded during our 2008-2011 period of sampling, our data confirm that African dust wet deposition constitutes the major atmospheric source for $\mathrm{Fe}$ and $\mathrm{Si}$ to the northwestern Mediterranean and an important source for $\mathrm{Cr}, \mathrm{Mn}, \mathrm{Ni}$, and V (1/3 of their total fluxes). 


\subsection{Source apportionment and background deposition}

In order to perform a source apportionment with the PMF method, we excluded the 12 samples corresponding to the events of high African dust deposition in order to address background atmospheric deposition. We evaluated PMF solutions with two to six factors. Finally, a solution with four factors has been chosen since it is the optimum solution, coupling a good agreement with our understanding of source identification and the indicator of PMF optimization. The four-factor solution was the most stable, with a sharper decrease in the $Q / Q_{\exp }$ trend and a constant global minimum $Q$ value among 100 random runs. In terms of the stability of the PMF analysis, all factors of the four-factor solution were reproduced in $100 \%$ of bootstrap runs, demonstrating that this solution was stable. No correlation among the four factors has been observed, indicating that they represented distinct sources. The four-factor solution enables us to apportion the results among the four sources: a dust factor (related to $\mathrm{Si}, \mathrm{Al}, \mathrm{Ca}, \mathrm{Fe}$, and $\mathrm{Ti}$ ), a marine aerosol factor (related to $\mathrm{Na}, \mathrm{Mg}$, and $\mathrm{Sr}$ ), an anthropogenic source factor (related to $\mathrm{Cr}, \mathrm{Pb}, \mathrm{V}, \mathrm{N}$, and $\mathrm{Sexc}$ ), and a biomass burning factor (related to $\mathrm{K}, \mathrm{P}, \mathrm{Zn}, \mathrm{Cu}$, and $\mathrm{Mn}$ ) (Fig. 5). This source identification is based on the presence of tracer elements as well as on the ratio of the elements in the source profile. The source identification was also supported by the seasonal contributions of each source to the atmospheric fluxes shown in Fig. 5. The identification of factors was supported by previous works on source apportionment of aerosol particles in the Mediterranean (Calzolai et al., 2015; Becagli et al., 2012, 2017). However, even if the oil combustion source (rich in $\mathrm{Ni}-\mathrm{V}$ ) has been typically observed in the central Mediterranean, no PMF solution (two- to sixfactor solutions) enabled us to extract a $\mathrm{Ni}-\mathrm{V}$ factor, corresponding to a ship plume signature. The heavy oil combustion signature could be contained in the anthropogenic factor. However, the typical V/Ni ratio of ship emissions is between 2.5 and 4.5 (Becagli et al., 2012), whereas this ratio is higher than 8 in the anthropogenic factor, suggesting that ship plumes are not dominant in this factor. Even if this source could be important for aerosol concentrations over the Mediterranean Sea (Becagli et al., 2017), it does not seem to be important for deposition in Corsica. The marine factor is marked by $\mathrm{Na}, \mathrm{Sss}, \mathrm{Mg}$, and $\mathrm{Sr}$, with at least $60 \%$ of their fluxes corresponding to this source. The elemental ratio obtained for this source $(\mathrm{Mg} / \mathrm{Na}=0.13 ; \mathrm{K} / \mathrm{Na}=$ $\left.0.064 ; \mathrm{Ca} / \mathrm{Na}=0.070, \mathrm{Sr} / \mathrm{Na}=8.5 \times 10^{-4}\right)$ is in agreement with the typical elemental ratio in seawater $(\mathrm{Mg} / \mathrm{Na}=0.12$; $\mathrm{K} / \mathrm{Na}=0.037 ; \mathrm{Ca} / \mathrm{Na}=0.038 ; \mathrm{Sr} / \mathrm{Na}=7 \times 10^{-4}$; Bowen, 1979). It is known that sea salt aerosol concentrations are a function of surface wind speeds (O'Dowd et al., 1993). The seasonal contribution of this source is consistent with a larger wind production in fall and winter, with a maximum of deposition in agreement with the maximum of rain in fall. $\mathrm{Na}$ comprises at least $15 \%$ for dust and biomass burning fac- tors in the total mass due to the high influence of the marine environment on Corsica. The factor identified as a dust source, marked by $\mathrm{Al}, \mathrm{Fe}, \mathrm{Si}$, and $\mathrm{Ti}$, is in agreement with the typical seasonal variation in dust deposition in Corsica, with a maximum in spring and in fall (Bergametti et al., 1989). Moreover, the elemental ratios $(\mathrm{Si} / \mathrm{Al}=2.7 ; \mathrm{Fe} / \mathrm{Al}=0.72$; $\mathrm{Ti} / \mathrm{Fe}=0.12)$ correspond to a Saharan dust signature $(\mathrm{Si} / \mathrm{Al}$ between 2 and 4 and Ti/Fe between 0.1 and 0.15; Formenti et al., 2014), but also with the typical ratio found in $\mathrm{PM}_{10}$ in remote areas in the Mediterranean (Alastuey et al., 2016). The biomass burning/waste source is mainly characterized by $\mathrm{Cu}$, $\mathrm{K}, \mathrm{P}$, and $\mathrm{Zn}$. $\mathrm{K}$ is commonly associated with waste/biomass burning or wood combustion (Dall'osto et al., 2013; Nava et al., 2015). The maximum of this source deposition in summer, in spite of a minimum of rain, corresponds with the intense forest fires observed in the Mediterranean region in this period, and which impact the entire basin (Bossioli et al., 2016). Finally, Cr, Pb, V, Sexc, and $\mathrm{N}$ are the characterizing elements found in the anthropogenic source. Even with solutions with more than four factors, no profile distinguishing N, Sexc, and metals is emphasized by PMF, suggesting a common source, at least geographically. Thus, the major contribution of $\mathrm{N}$ and Sexc in mixing with metals suggests that this source corresponds with the secondary aerosols formed in air masses issued from combustion sources (traffic, industrial). The two sources of combustion identified by PMF, i.e., biomass burning and anthropogenic sources, have previously been observed in background aerosols at another remote site in Corsica (Arndt et al., 2017; Claeys et al., 2017).

In Fig. 6, we show the relative contribution from the identified sources to the background deposition flux of nutrients and TMs. The results show that the combustion sources (biomass burning or anthropogenic) predominate in the background inputs of major nutrients and TMs, except Fe and $\mathrm{Si}$. Even for background deposition, the source apportionment of $\mathrm{Fe}$ and $\mathrm{Si}$ is quasi-similar to $\mathrm{Al}$ (correlation coefficient is close to 1 for the elemental fluxes even for intense events and the ratios of $\mathrm{Si} / \mathrm{Al}$ and $\mathrm{Fe} / \mathrm{Al}$ are characteristic of mineral dust). These results suggest that even if the PMF apportionment source distributes the fluxes from the four sources, in all the cases, the fluxes of $\mathrm{Fe}$ and $\mathrm{Si}$ are associated with mineral dust sources, most probably Saharan dust.

Concerning major nutrients, $\mathrm{P}$ deposition is highly associated with biomass burning inputs out of the most intense dust deposition events. Considering that dust deposition accounts for $15 \%$ of the total $\mathrm{P}$ deposition flux (including intense dust deposition events + background deposition), almost $85 \%$ of $\mathrm{P}$ inputs are associated with the deposition of biomass burning, waste, and wood-related aerosol. This confirms the importance of considering the biomass combustion source to estimate the role of this element in the marine environment in the Mediterranean. For $\mathrm{N}$ deposition, the inputs associated with marine sources are quasi-similar to the inputs from combustion sources. Thus, almost $50 \%$ of $\mathrm{N}$ fluxes are explained by the marine source. Several works observed 

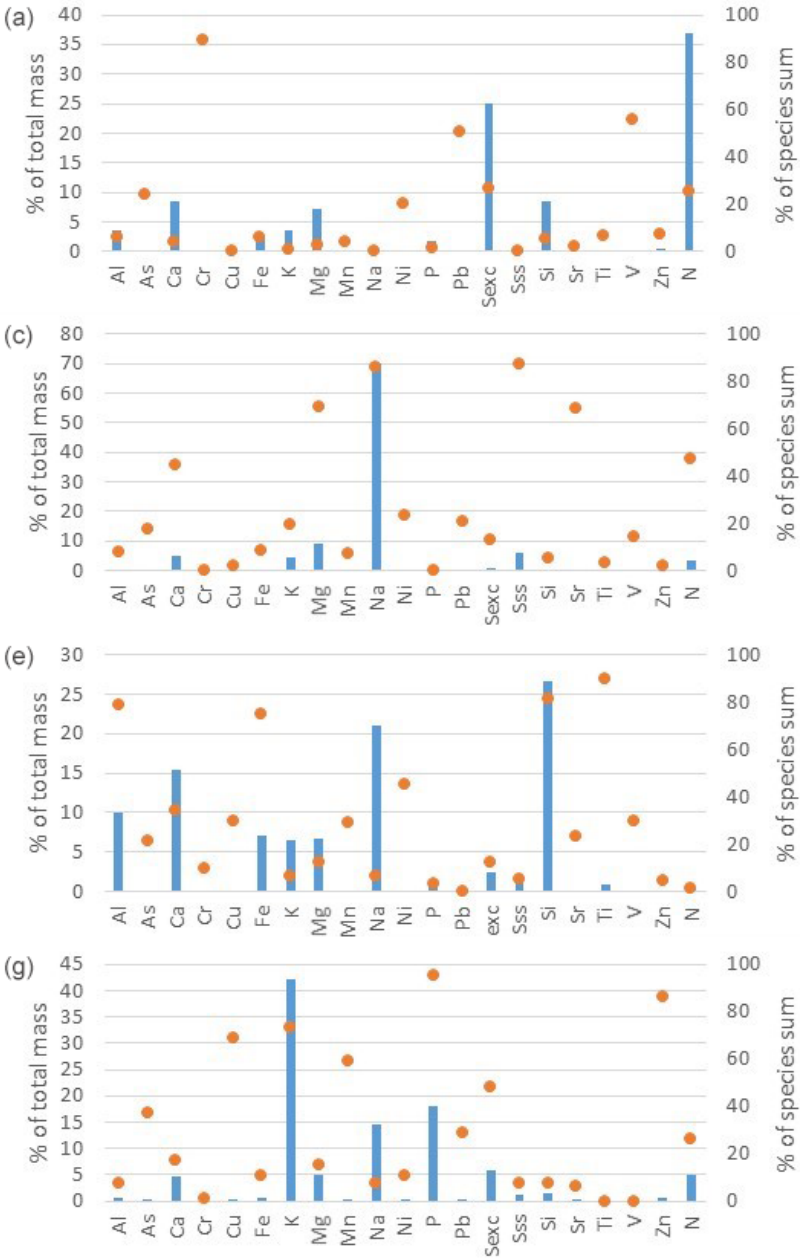
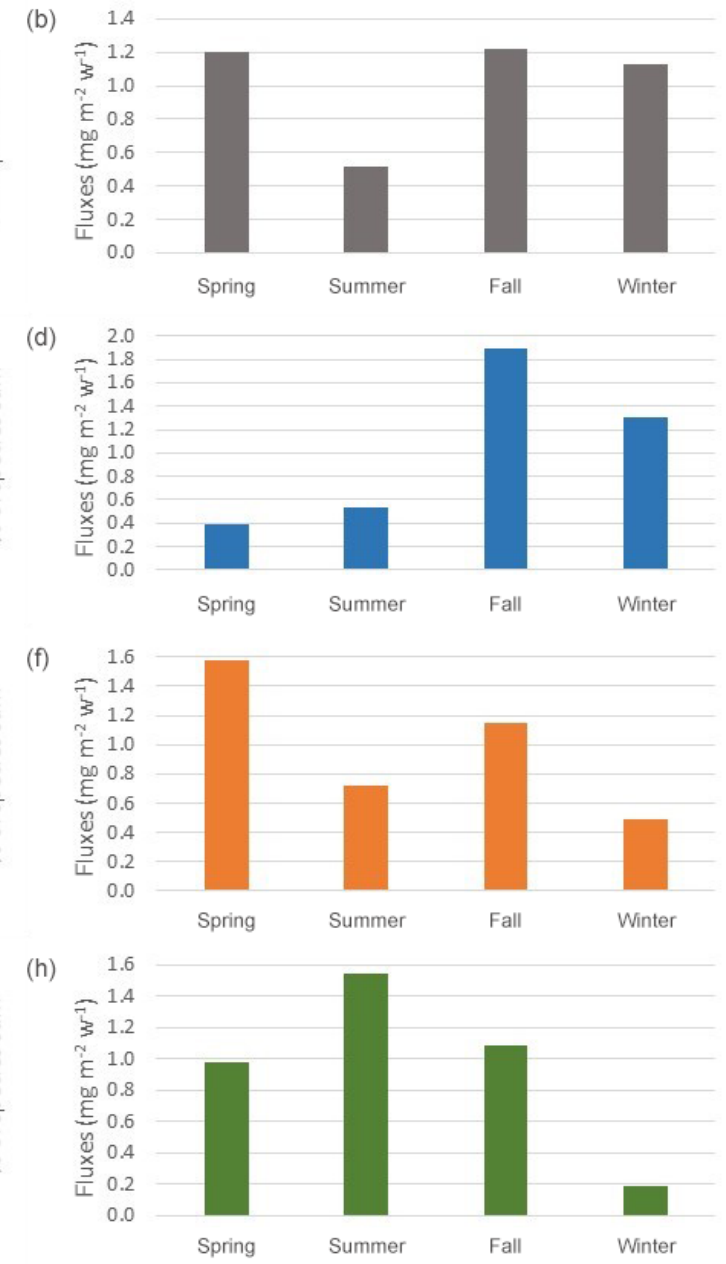

Figure 5. PMF-derived profiles of the four sources identified. From top to bottom: (a) anthropogenic, (c) marine, (e) dust, and (g) biomass burning including the fraction of total mass (blue columns) and fraction of the elemental sum (orange circles) for the various elements (left side). Normalized seasonal contributions of these four respective factors (b, $\mathbf{d}, \mathbf{f}, \mathbf{h}$ ), excluding the 10 most intense dust events (right side).

that the depletion of chloride $(\mathrm{Cl})$ and the simultaneous occurrence of $\mathrm{NO}_{3}$ in sea salt aerosol particles is due to the reaction between $\mathrm{NaCl}$ and $\mathrm{HNO}_{3}$ when maritime and anthropogenic air masses are mixed, in Mediterranean environments (Sellegri et al., 2001; Bardouki et al., 2003; Pey et al., 2009) and in particular in Corsica (Claeys et al., 2017). The contribution of marine source to $\mathrm{N}$ deposition is probably due to the deposition of these processed sea salt particles. In the case of the anthropogenic source factor, the good correlation obtained between $\mathrm{N}$ and Sexc supports a common origin, which is probably associated with the inorganic secondary aerosol, i.e., ammonium sulfate. Indeed, ammonium sulfate aerosols are currently observed in Corsica due to regional transport (Arndt et al., 2017) and generally at the remote Mediterranean sites (e.g., Calzolai et al., 2015). As stated previously, the use of $\mathrm{N}$ speciation is limited by the preservation conditions of our samples. However, we observed a concomitance between the highest deposited mass of $\mathrm{NH}_{4}^{+}$and Sexc, and of $\mathrm{NO}_{3}^{-}$and $\mathrm{Na}$ (see Supplement). This reinforces our conclusion about a partition between $\mathrm{N}$, as $\mathrm{NH}_{4}^{+}$is mainly associated with ammonium sulfate for the anthropogenic factor, and $\mathrm{N}$, as $\mathrm{NO}_{3}^{-}$is present as $\mathrm{NaNO}_{3}$ for the marine factor. It is known that the deposition efficiency of particles in the coarse mode, as sea salts, is higher than that of fine particles, as inorganic secondary aerosols. Our results suggest that the addition of nitrate to sea salt particles could be a key process in controlling the $\mathrm{N}$ atmospheric deposition fluxes to Mediterranean surface waters. Recent works suggest that a large part of nitrogen associated with anthropogenic secondary aerosol could be soluble organic nitrogen (Violaki et al., 2015). Thus, the observed diversity in sources of deposited $\mathrm{N}$ could also mean a difference in $\mathrm{N}$ speciation in the fallout (inorganic vs. organic).

For TMs, marine sources present the lowest contribution. The biomass burning/waste source is clearly predominant for $\mathrm{Cu}, \mathrm{Mn}$, and $\mathrm{Zn}$, whereas atmospheric fluxes of $\mathrm{Cr}$ and $\mathrm{Ni}$ are 


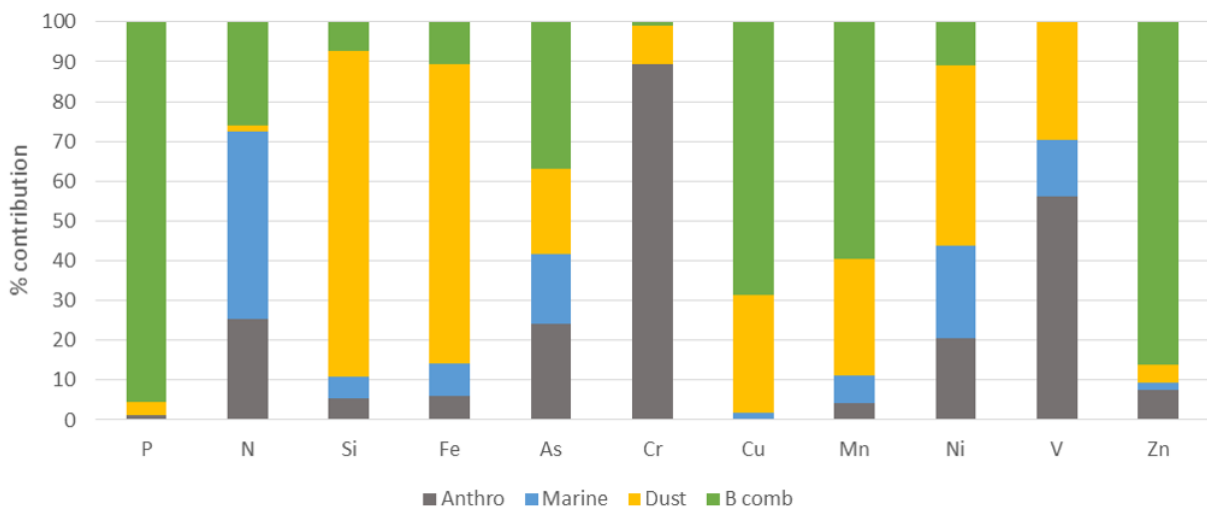

Figure 6. Relative contribution of each of the four identified factors (anthropogenic (Anthro), marine, dust, and biomass combustion (B comb)) to the "background" mass fluxes of nutrients and TMs (i.e., excluding the 12 most intense African dust deposition samples out of 195 samples).

largely linked to the anthropogenic source. Fu et al. (2017) show that the Cr deposition in Cape Corsica, even during intense dust events, originates from an anthropogenic source, suggesting a contamination by a local source. Even if Cape Corsica and our sites of deposition measurements are about $100 \mathrm{~km}$ apart, both suggest that $\mathrm{Cr}$ deposition is controlled by an anthropogenic source. For Zn, Guieu et al. (2010) also showed a large contribution of a non-dust source. Our work supports their conclusions and allows the identification of a biomass combustion source rather than a fossil fuel or industrial source. It appears that the deposition of $\mathrm{Cu}, \mathrm{Mn}, \mathrm{Ni}$, and $\mathrm{V}$ is influenced, at least for $20 \%$, by dust deposition out of intense events. That means that for these TMs, the natural dust inputs can represent up to $50 \%$ of annual fluxes.

\subsection{Biogeochemical implications}

The typical $\mathrm{N}$ : P molar ratio in seawater required by marine phytoplankton corresponds to a Redfield ratio of 16 . This ratio is generally higher in Mediterranean surface seawater, with values ranging from 20 to 100 in the basin (Ribera d'Alcala et al., 2003). The atmospheric input to the Mediterranean Sea displays a high N : P ratio for dissolved or soluble inorganic forms (Herut and Krom, 1996), which could be one possible reason for the high $\mathrm{N}: \mathrm{P}$ ratio in Mediterranean deep seawaters (Markaki et al., 2010; Krom et al., 2010).

In our dataset, the yearly deposition mass fluxes measured for $\mathrm{N}$ and $\mathrm{P}$ are quasi-equivalent $\left(0.14-0.15 \mathrm{~g} \mathrm{~m}^{-2} \mathrm{yr}^{-1}\right.$; Table 1). However, weekly measurements show a very large variability in $\mathrm{P}$ fluxes, contrary to $\mathrm{N}$. Hence, a large variability in the $\mathrm{N}: \mathrm{P}$ molar ratio is observed in the atmospheric inputs at short timescales. A mean value of 35 is observed for the molar ratio but the weekly ratio ranges from 0.4 to 1220 . The observed $\mathrm{N}$ enrichment in comparison to the Redfield ratio is in agreement with previous observations showing a preponderance of $\mathrm{N}$ relative to $\mathrm{P}$ in the atmospheric deposition over the Mediterranean Sea (Markaki et al., 2010). How- ever, a detailed analysis shows that the atmospheric ratio is equal to or higher than the Redfield ratio for only $25 \%$ of samples and higher than 160 for only three samples $(4 \%)$. This value reaches $36 \%$ for the wet periods. The higher ratio observed in wet deposition could be linked to a washout effect of the gaseous $\mathrm{N}$ species (as $\mathrm{NO}_{x}, \mathrm{NH}_{3}$ ) by rain (OchoaHueso et al., 2011). The intense dust events present an average $\mathrm{N}$ : $\mathrm{P}$ ratio of 3.5 , which is lower than previously reported for dust deposition (between 30 and 70; Morales-Baquero et al., 2013). However, this value is consistent with the typical $\mathrm{N}$ : P ratio in Saharan dust aerosols, which is around 2.5. The highest $\mathrm{N}$ : $\mathrm{P}$ ratios are generally due to the reactivity of dust aerosol with gaseous nitric acid to form nitrate on dust particles (Desboeufs et al., 2014). Our data suggest that the effect of mixing between dust and nitric acid did not commonly affect atmospheric dust deposited in Corsica, except maybe during certain high dust deposition. On the contrary, the mixing between sea salt and nitric acid identified with the source apportionment could be a source of $\mathrm{N}$ during the fall and winter periods, when the biomass burning source is negligible. It also appears that the lowest $\mathrm{N}: \mathrm{P}$ ratio values are mainly observed from May to September (Fig. 7). During this period, atmospheric deposition becomes the main source of nutrients since the Mediterranean is highly stratified and the surface is depleted in nutrients. Thus, in these conditions, the atmospheric inputs will be deficient in $\mathrm{N}$ relative to phytoplankton requirements. Studies show that phytoplankton growth in western Mediterranean waters is usually limited by a lack of phosphate rather than nitrate in summer (Lazzari et al., 2016; Richon et al., 2018a), even if phosphorus addition experiments have also indicated $\mathrm{N}$ limitation in this period (Tanaka et al., 2011). Our results suggest that the role of atmospheric aerosol input will be rather favorable in the case of $\mathrm{P}$ starvation of surface seawater. However, even if the $\mathrm{N}$ : P ratio from this study were obtained with deposition collectors comparable to previous literature (e.g., Markaki et al., 2010), it has 


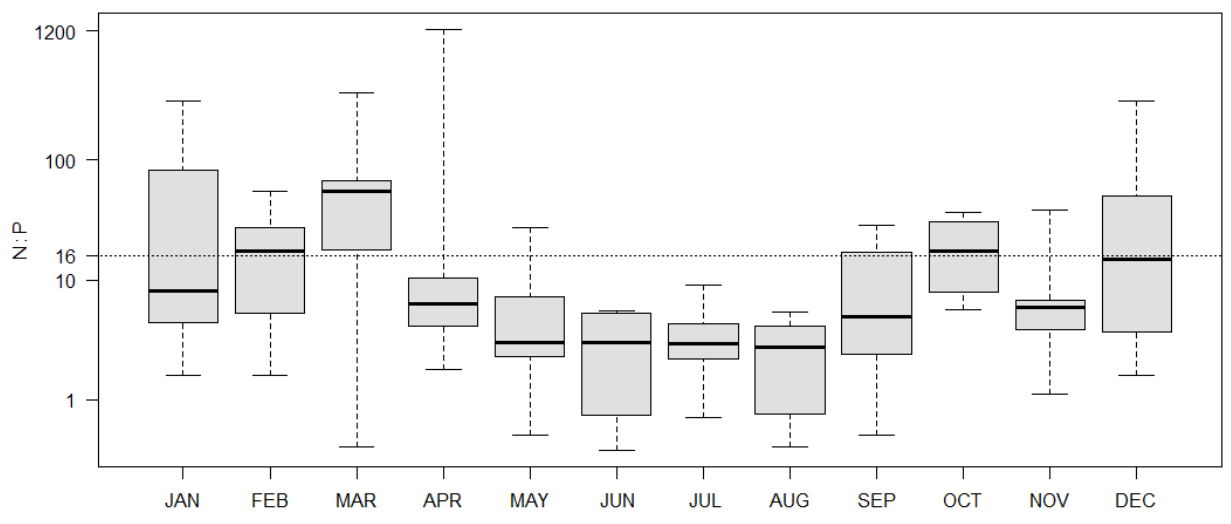

Figure 7. Box plots of monthly molar N : P ratio in deposition samples, showing the third quartile (Q3) and first quartile (Q1) ranges of the data and minimum and maximum of data. For the sake of comparison, the N : P scale is logarithmic and the Redfield ratio is displayed.

to be kept in mind that the deposition collectors were not optimized for gaseous $\mathrm{N}$ flux measurements, and the $\mathrm{N}$ : P ratio could be underestimated. The temporal evolution of marine $\mathrm{N}$ and $\mathrm{P}$ concentrations since 1985 has shown a high sensitivity to anthropogenic atmospheric deposition and they are expected to decline in the coming decades due to mitigation/control of pollutant emissions (Moon et al., 2016). Due to the high contribution of anthropogenic deposition sources to atmospheric $\mathrm{P}$ fluxes emphasized by our study, it is important to include precise anthropogenic $\mathrm{P}$ emission inventories to estimate the impact of atmospheric deposition on carbon fluxes and phytoplankton biomass in the future.

\section{Conclusions}

In a context of anthropogenic changes, in order to assess how the evolution of chemical atmospheric forcing will modify the marine nutrient cycling, it is crucial to distinguish between anthropogenic and natural atmospheric inputs of nutrients to oligotrophic Mediterranean surface waters. We monitored elemental atmospheric deposition on a weekly basis over 3.5 years (March 2008-October 2011) at a coastal site on the western coast of Corsica. The contribution of four different source types to the fallout of nutrients and TMs was determined using the statistical PMF method, namely desert dust, sea salt, anthropogenic activities, and biomass combustion sources. The data show that $\mathrm{Si}$ and Fe fluxes are typically related to African dust deposition, with fluxes dominated by high-dust-deposition events. A typical $\mathrm{Si} / \mathrm{Al}$ ratio of 2.5 is obtained for all the samples. This shows that $\mathrm{Al}$ is a good proxy to estimate the Si fluxes in the Mediterranean region since $\mathrm{Si}$ is often not measured when $\mathrm{X}$-ray fluorescence spectrometry is not available due its loss by hydrofluoric acid digestion during the protocol of chemical analysis. Our results on mineral dust fallout are of the same order of magnitude as that in 2013 at another site in Corsica (Vincent et al., 2016) and confirm the fact that dust deposition has strongly decreased in Corsica in recent years compared to the 1980s and 1990s, with no observed occurrence of a high-dust-deposition event larger than $1 \mathrm{~g} \mathrm{~m}^{-2}$ in 2008-2011 (this work) and 2013 (Vincent et al., 2016).

Atmospheric fluxes of $\mathrm{Cu}, \mathrm{Mn}, \mathrm{Ni}$, and $\mathrm{V}$ are also associated by at least at $50 \%$ with mineral dust deposition, whereas half of atmospheric fluxes are issued from biomass burning particle deposition ( $\mathrm{Cu}$ and $\mathrm{Mn}$ ), from fossil fuel combustion $(\mathrm{V})$, or both $(\mathrm{Ni})$. The anthropogenic/combustion sources govern the atmospheric fluxes of the major nutrients $\mathrm{N}$ and $\mathrm{P}$, with a predominance of a biomass combustion source for $\mathrm{P}$ and secondary aerosols for N. Dust deposition contributes around $15 \%$ of deposited $\mathrm{P}$ at the yearly timescale. Confirming recent model results that desert dust is not dominant in atmospheric P fluxes (Richon et al., 2018b), our results show that these combustion sources need to be considered in $\mathrm{P}$ deposition modeling. Finally, $\mathrm{Zn}$ or $\mathrm{Cr}$ deposition is very largely associated with continuous combustion sources.

This work is a first tentative assessment of the origin of nutrients and TMs deposited in the western Mediterranean. Of course, our study is not sufficient to apprehend the spatial variability in the influence of the identified source types over the basin. It needs to be supported by other studies of source apportionment in deposition samples in the region.

Data availability. All the data used in this article are available in Supplement.

Supplement. The supplement related to this article is available online at: https://doi.org/10.5194/acp-18-14477-2018-supplement.

Author contributions. KD and EBN ensured the preparation and the transfer of the deposition samples. EBN, SC and ST conducted the sample analysis. KD and FD contributed to developing the scientific direction. KD directed this work and wrote the manuscript. 
Competing interests. The authors declare that they have no conflict of interest.

Special issue statement. This article is part of the special issue "CHemistry and AeRosols Mediterranean EXperiments (ChArMEx) (ACP/AMT inter-journal SI)". It is not associated with a conference.

Acknowledgements. The authors wish to warmly thank Pasquale Simeoni from Parc Naturel Régional de Corse, who made possible the weekly sample collection and the maintenance of the sampling site. This study received financial support from the French ANR through the project DUNE and from the MISTRALS program funded by INSU, ADEME, CEA, and Météo-France. This study contributes to WP5 on Atmospheric Deposition of the MISTRALS/ChArMEx project. The authors want to thank Rémi Losno for his involvement in the installation of deposition collectors and the staff of the Parc Naturel Régional de Corse for assistance in sampling.

Edited by: Nikolaos Mihalopoulos

Reviewed by: two anonymous referees

\section{References}

Alastuey, A., Querol, X., Aas, W., Lucarelli, F., Pérez, N., Moreno, T., Cavalli, F., Areskoug, H., Balan, V., Catrambone, M., Ceburnis, D., Cerro, J. C., Conil, S., Gevorgyan, L., Hueglin, C., Imre, K., Jaffrezo, J.-L., Leeson, S. R., Mihalopoulos, N., Mitosinkova, M., O’Dowd, C. D., Pey, J., Putaud, J.-P., Riffault, V., Ripoll, A., Sciare, J., Sellegri, K., Spindler, G., and Yttri, K. E.: Geochemistry of $\mathrm{PM}_{10}$ over Europe during the EMEP intensive measurement periods in summer 2012 and winter 2013, Atmos. Chem. Phys., 16, 6107-6129, https://doi.org/10.5194/acp16-6107-2016, 2016.

Amato, F., Alastuey, A., Karanasiou, A., Lucarelli, F., Nava, S., Calzolai, G., Severi, M., Becagli, S., Gianelle, V. L., Colombi, C., Alves, C., Custódio, D., Nunes, T., Cerqueira, M., Pio, C., Eleftheriadis, K., Diapouli, E., Reche, C., Minguillón, M. C., Manousakas, M.-I., Maggos, T., Vratolis, S., Harrison, R. M., and Querol, X.: AIRUSE-LIFE+: a harmonized PM speciation and source apportionment in five southern European cities, Atmos. Chem. Phys., 16, 3289-3309, https://doi.org/10.5194/acp16-3289-2016, 2016.

Arndt, J., Sciare, J., Mallet, M., Roberts, G. C., Marchand, N., Sartelet, K., Sellegri, K., Dulac, F., Healy, R. M., and Wenger, J. C.: Sources and mixing state of summertime background aerosol in the north-western Mediterranean basin, Atmos. Chem. Phys., 17, 6975-7001, https://doi.org/10.5194/acp17-6975-2017, 2017.

Bardouki, H., Liakakou, H., Economou, C., Sciare, J., Smolik, J., Zdimal, V., Eleftheriadis, K., Lazaridis, M., Dye, C., and Mihalopoulos, N.: Chemical composition of sizeresolved atmospheric aerosols in the eastern Mediterranean during summer and winter, Atmos. Environ., 37, 195-208, https://doi.org/10.1016/S1352-2310(02)00859-2, 2003.
Becagli, S., Sferlazzo, D. M., Pace, G., di Sarra, A., Bommarito, C., Calzolai, G., Ghedini, C., Lucarelli, F., Meloni, D., Monteleone, F., Severi, M., Traversi, R., and Udisti, R.: Evidence for heavy fuel oil combustion aerosols from chemical analyses at the island of Lampedusa: a possible large role of ships emissions in the Mediterranean, Atmos. Chem. Phys., 12, 3479-3492, https://doi.org/10.5194/acp-12-3479-2012, 2012.

Becagli, S., Anello, F., Bommarito, C., Cassola, F., Calzolai, G., Di Iorio, T., di Sarra, A., Gómez-Amo, J.-L., Lucarelli, F., Marconi, M., Meloni, D., Monteleone, F., Nava, S., Pace, G., Severi, M., Sferlazzo, D. M., Traversi, R., and Udisti, R.: Constraining the ship contribution to the aerosol of the central Mediterranean, Atmos. Chem. Phys., 17, 2067-2084, https://doi.org/10.5194/acp17-2067-2017, 2017.

Bergametti, G.: Apports de matière par voie atmosphéirique à la Méditerraneé Occidentale: aspects géochimiques et météorologiques, PhD, 296 pp., Univ. Paris VII, Paris, 1987.

Bergametti, G., Dutot, A. L., Buat-Ménard, P., Losno, R., and Remoudaki, E.: Seasonal variability of the elemental composition of atmospheric aerosol particles over the Northwestern Mediterranean, Tellus, 41B, 353-361, https://doi.org/10.1111/j.16000889.1989.tb00314.x, 1989.

Bergametti, G., Remoudaki, E., Losno, R., Steiner, E., Chatenet B., and Buat-Ménard, P.: Sources, transport and deposition of atmospheric phosphorus over the northwestern Mediterranean, J. Atmos. Chem., 14, 501-513, https://doi.org/10.1007/BF00115254, 1992.

Bethoux J.-P., Courau, P., Nicolas, E., and Ruiz-Pino, D.: Tracemetal pollution in the Mediterranean-sea, Oceanol. Acta, 13, 481-488, 1990.

Bonnet, S. and Guieu, C.: Atmospheric forcing on the annual iron cycle in the western Mediterranean Sea: A 1-year survey, J. Geophys. Res.-Oceans, 111, https://doi.org/10.1029/2005JC003213, 2006.

Bossioli, E., Tombrou, M., Kalogiros, J., Allan, J., Bacak, A., Bezantakos, S., Biskos, G., Coe, H., Jones, B. T., Kouvarakis, G., Mihalopoulos, N., and Percival, C. J.: Atmospheric composition in the Eastern Mediterranean: Influence of biomass burning during summertime using the WRF-Chem model, Atmos. Environ., 132, 317-331, https://doi.org/10.1016/j.atmosenv.2016.03.011, 2016.

Bowen, H. J. M.: Environmental chemistry of the elements, Academic Press, 1979.

Calzolai, G., Nava, S., Lucarelli, F., Chiari, M., Giannoni, M., Becagli, S., Traversi, R., Marconi, M., Frosini, D., Severi, M., Udisti, R., di Sarra, A., Pace, G., Meloni, D., Bommarito, C., Monteleone, F., Anello, F., and Sferlazzo, D. M.: Characterization of $\mathrm{PM}_{10}$ sources in the central Mediterranean, Atmos. Chem. Phys., 15, 13939-13955, https://doi.org/10.5194/acp-1513939-2015, 2015.

Chester, R., Nimmo, M., and Keyse, S.: The influence of saharan and middle eastern desert-derived dust on the trace metal composition on Mediterranean aerosols and rainwaters: an overview, in: The impact of Desert dust across the Mediterranean, edited by: Guerzoni, S. and Chester, R., Kluwer Academic Publishers, Dordrecht, 253-273, 1996.

Claeys, M., Roberts, G., Mallet, M., Arndt, J., Sellegri, K., Sciare, J., Wenger, J., and Sauvage, B.: Optical, physical and chemical properties of aerosols transported to a coastal site in the 
western Mediterranean: a focus on primary marine aerosols, Atmos. Chem. Phys., 17, 7891-7915, https://doi.org/10.5194/acp17-7891-2017, 2017.

Dall'Osto, M., Querol, X., Amato, F., Karanasiou, A., Lucarelli, F., Nava, S., Calzolai, G., and Chiari, M.: Hourly elemental concentrations in $\mathrm{PM}_{2.5}$ aerosols sampled simultaneously at urban background and road site during SAPUSS - diurnal variations and PMF receptor modelling, Atmos. Chem. Phys., 13, 43754392, https://doi.org/10.5194/acp-13-4375-2013, 2013.

Desboeufs, K., Leblond, N., Wagener, T., Bon Nguyen, E., and Guieu, C.: Chemical fate and settling of mineral dust in surface seawater after atmospheric deposition observed from dust seeding experiments in large mesocosms, Biogeosciences, 11, 55815594, https://doi.org/10.5194/bg-11-5581-2014, 2014.

Diapouli, E., Manousakas, M. I., Vratolis, S., Vasilatou, V., Pateraki, S., Bairachtari, K. A., Querol, X., Amato, F., Alastuey, A., Karanasiou, A. A., Lucarelli, F., Nava, S., Calzolai, G., Gianelle, V. L., Colombi, C., Alves, C., Custódio, D., Pio, C., Spyrou, C., Kallos, G. B., and Eleftheriadis, K.: AIRUSE-LIFE +: estimation of natural source contributions to urban ambient air $\mathrm{PM}_{10}$ and $\mathrm{PM}_{2.5}$ concentrations in southern Europe - implications to compliance with limit values, Atmos. Chem. Phys., 17, 3673-3685, https://doi.org/10.5194/acp-17-3673-2017, 2017.

Dulac, F., Buat-Ménard, P., Arnold, M., Ezat, U., and Martin, D.: Atmospheric input of trace metals to the western Mediterranean Sea: 1. Factors controlling the variability of atmospheric concentrations, J. Geophys. Res., 92, 8437-8453, https://doi.org/10.1029/JD092iD07p08437, 1987.

Evan, A. T., Flamant, C., Gaetani, M., and Guichard, F.: The past, present and future of African dust, Nature, 531, 493, https://doi.org/10.1038/nature17149, 2016.

Formenti, P., Rajot, J. L., Desboeufs, K., Caquineau, S., Chevaillier, S., Nava, S., Gaudichet, A., Journet, E., Triquet, S., Alfaro, S., Chiari, M., Haywood, J., Coe, H., and Highwood, E.: Regional variability of the composition of mineral dust from western Africa: Results from the AMMA SOP0/DABEX and DODO field campaigns, J. Geophys. Res.-Atmos., 113, D00C13, https://doi.org/10.1029/2008JD009903, 2008.

Formenti, P., Schütz, L., Balkanski, Y., Desboeufs, K., Ebert, M., Kandler, K., Petzold, A., Scheuvens, D., Weinbruch, S., and Zhang, D.: Recent progress in understanding physical and chemical properties of African and Asian mineral dust, Atmos. Chem. Phys., 11, 8231-8256, https://doi.org/10.5194/acp11-8231-2011, 2011.

Formenti, P., Caquineau, S., Desboeufs, K., Klaver, A., Chevaillier, S., Journet, E., and Rajot, J. L.: Mapping the physicochemical properties of mineral dust in western Africa: mineralogical composition, Atmos. Chem. Phys., 14, 10663-10686, https://doi.org/10.5194/acp-14-10663-2014, 2014.

Fu, Y., Desboeufs, K., Vincent, J., Bon Nguyen, E., Laurent, B., Losno, R., and Dulac, F.: Estimating chemical composition of atmospheric deposition fluxes from mineral insoluble particles deposition collected in the western Mediterranean region, Atmos. Meas. Tech., 10, 4389-4401, https://doi.org/10.5194/amt10-4389-2017, 2017.

Gallisai, R., Peters, F., Volpe, G., Basart, S., and Baldasano, J. M.: Saharan Dust Deposition May Affect Phytoplankton Growth in the Mediterranean Sea at Ecological Time Scales, PLoS ONE, 9, e110762, https://doi.org/10.1371/journal.pone.0110762, 2014.
Gratz, L. E., Keeler, G. J., Morishita, M., Barres, J. A., and Dvonch, J. T.: Assessing the emission sources of atmospheric mercury in wet deposition across Illinois, Sci. Total Environ., 448, 120-131, https://doi.org/10.1016/j.scitotenv.2012.11.011, 2013.

Guerzoni, S., Chester, R., Dulac, F., Herut, B., Loÿe-Pilot, M.D., Measures, C., Migon, C., Molinaroli, E., Moulin, C., and Rossini, P.: The role of atmospheric deposition in the biogeochemistry of the Mediterranean Sea, Prog. Oceanogr., 44, 147190, https://doi.org/10.1016/S0079-6611(99)00024-5, 1999a.

Guerzoni, S., Molinaroli, E., Rossini, P., Rampazzo, G., Quarantotto, G., De Falco, G., and Cristini, S.: Role of desert aerosol in metal fluxes in the Mediterranean area, Chemosphere, 39, 229246, $1999 b$.

Guieu, C., Chester, R., Nimmo, M., Martin, J.-M., Guerzoni, S., Nicolas, E., Mateu, J., and Keyse, S.: Atmospheric input of dissolved and particulate metals to the northwestern Mediterranean, Deep-Sea Res. Pt. II, 44, 655-674, https://doi.org/10.1016/S0967-0645(97)88508-6, 1997.

Guieu, C., Loÿe-Pilot, M. D., Benyahya, L., and Dufour, A.: Spatial variability of atmospheric fluxes of metals $(\mathrm{Al}, \mathrm{Fe}, \mathrm{Cd}, \mathrm{Zn}$ and $\mathrm{Pb}$ ) and phosphorus over the whole Mediterranean from a one-year monitoring experiment: Biogeochemical implications, Mar. Chem., 120, 164-178, https://doi.org/10.1016/j.marchem.2009.02.004, 2010.

Heimburger, A., Losno, R., Triquet, S., Dulac, F., and Mahowald, N. C. G.: Direct measurements of atmospheric iron, cobalt, and aluminum-derived dust deposition at Kerguelen Islands, Global Biogeochem. Cy., 26, https://doi.org/10.1029/2012gb004301, 2012.

Henderson, P. and Henderson, G. M.: Earth science data, Cambridge University Press, 92-97, 2009.

Herut B. and Krom, M.: Atmospheric Input of Nutrients and Dust to the SE Mediterranean, in: The Impact of Desert Dust Across the Mediterranean, edited by: Guerzoni, S. and Chester, R., Environmental Science and Technology Library, vol 11., Springer, Dordrecht, 1996.

Hovmand, M. F., Kemp, K., Kystol, J., Johnsen, I., RiisNielsen, T., and Pacyna, J. M.: Atmospheric heavy metal deposition accumulated in rural forest soils of southern Scandinavia, Environ. Pollut., 155, 537-541, https://doi.org/10.1016/j.envpol.2008.01.047, 2008.

Keeler, G. J., Landis, M. S., Norris, G. A., Christianson, E. M., and Dvonch, J. T.: Sources of mercury wet deposition in Eastern Ohio, USA, Environ. Sci. Technol., 40, 5874-5881, https://doi.org/10.1021/es060377q, 2006.

Krom, M. D., Emeis, K. C., and Van Cappellen, P.: Why is the Eastern Mediterranean phosphorus limited?, Prog. Oceanogr., 85, 236-244, https://doi.org/10.1016/j.pocean.2010.03.003, 2010.

Lazzari, P., Solidoro, C., Salon, S., and Bolzon, G.: Spatial variability of phosphate and nitrate in the Mediterranean Sea: A modeling approach, Deep-Sea Res. Pt. I, 108, 39-52, https://doi.org/10.1016/j.dsr.2015.12.006, 2016.

Loÿe-Pilot, M. D. and Martin, J. M.: Saharan Dust Input to the Western Mediterranean: An Eleven Years Record in Corsica, in: The Impact of Desert Dust Across the Mediterranean, edited by: Guerzoni, S. and Chester, R., Kluwer, 191-199, 1996.

Loÿe-Pilot, M. D., Martin, J. M., and Morelli, J.: Atmospheric input of inorganic nitrogen to the Western Mediterranean, Bio- 
geochemistry, 9, 117-134, https://doi.org/10.1007/BF00692168, 1990.

Mahowald, N., Jickells, T. D., Baker, A. R., Artaxo, P., BenitezNelson, C. R., Bergametti, G., Bond, T. C., Chen, Y., Cohen, D. D., Herut, B., Kubilay, N., Losno, R., Luo, C., Maenhaut, W., McGee, K. A., Okin, G. S., Siefert, R. L., and Tsukuda, S.: Global distribution of atmospheric phosphorus sources, concentrations and deposition rates, and anthropogenic impacts, Global Biogeochem. Cy., 22, GB4026, https://doi.org/10.1029/2008gb003240, 2008.

Markaki, Z., Loÿe-Pilot, M. D., Violaki, K., Benyahya, L., and Mihalopoulos, N.: Variability of atmospheric deposition of dissolved nitrogen and phosphorus in the Mediterranean and possible link to the anomalous seawater N/P ratio, Mar. Chem., 120, 187-194, https://doi.org/10.1016/j.marchem.2008.10.005, 2010.

Mason, B. and Moore, C. B.: Principles of Geochemistry, Wiley, New York, pp331, 1982.

Moon, J. Y., Lee, K., Tanhua, T., Kress, N., and Kim, I. N.: Temporal nutrient dynamics in the Mediterranean Sea in response to anthropogenic inputs, Geophys. Res. Lett., 43, 5243-5251, https://doi.org/10.1002/2016GL068788, 2016.

Morabito, E., Contini, D., Belosi, F., Stortini, A. M., Manodori, L., and Gambaro, A.: Atmospheric Deposition of Inorganic Elements and Organic Compounds at the Inlets of the Venice Lagoon, Adv. Meteorol., 2014, 158902, https://doi.org/10.1155/2014/158902, 2014.

Morales-Baquero, R., Pulido-Villena, E., and Reche, I.: Chemical signature of Saharan dust on dry and wet atmospheric deposition in the south-western Mediterranean region, Tellus B, 65, 1, https://doi.org/10.3402/tellusb.v65i0.18720, 2013.

Morel, F. M. M. and Price, N. M.: The Biogeochemical Cycles of Trace Metals in the Oceans, Science, 300, 944-947, https://doi.org/10.1126/science.1083545, 2003.

Moulin, C., Lambert, C. E., Dulac, F., and Dayan, U.: Control of atmospheric export of dust from North Africa by the North Atlantic Oscillation, Nature, 387, 691-694, https://doi.org/10.1038/42679, 1997.

Moulin, C., Lambert, C. E., Dayan, U., Masson, V., Ramonet, M., Bousquet, P., Legrand, M., Balkanski, Y. J., Guelle, W., Marticorena, B., Bergametti, G., and Dulac, F.: Satellite climatology of African dust transport in the Mediterranean atmosphere, J. Geophys. Res., 103, 13137-13144, 1998,

Nava, S., Lucarelli, F., Amato, F., Becagli, S., Calzolai, G., Chiari, M., Giannoni, M., Traversi, R., and Udisti, R.: Biomass burning contributions estimated by synergistic coupling of daily and hourly aerosol composition records, Sci. Total Environ., 511, 1120, https://doi.org/10.1016/j.scitotenv.2014.11.034, 2015.

Norris, G., Duvall, R., and Brown, S.: EPA Positive Matrix Factorization (PMF) 5.0 Fundamentals \& User Guide, EPA, U.S., 2014.

Ochoa-Hueso, R., Allen, E. B., Branquinho, C., Cruz, C., Dias, T., Fenn, M. E., Manrique, E., Perez-Corona, M. E., Sheppard, L. J., and Stock, W. D.: Nitrogen deposition effects on Mediterraneantype ecosystems: An ecological assessment, Environ. Pollut., 159, 2265-2279, https://doi.org/10.1016/j.envpol.2010.12.019, 2011.

O'Dowd, C. D. and Smith, M. H.: Physicochemical properties of aerosols over the northeast Atlantic: Evidence for wind-speed related submicron sea-salt aerosol production, J. Geophys. Res., 98, 1137-1149, https://doi.org/10.1029/92JD02302, 1993.
Paatero, P.: Least squares formulation of robust non-negative factor analysis, Chemometr. Intell. Lab., 37, 23-35, 1997.

Paatero, P. and Tapper, U.: Positive matrix factorization a non-negative factor model with optimal utilization of error-estimates of data values, Environmetrics, 5, 111-126, https://doi.org/10.1002/env.3170050203, 1994.

Pasqueron de Fommervault, O., Migon, C., Dufour, A., D’Ortenzio, F., Kessouri, F., Raimbault, P., Garcia, N., and Lagadec, V.: Atmospheric input of inorganic nitrogen and phosphorous to the Ligurian Sea: Data from the Cap Ferrat coastal time-series station, Deep-Sea Res. Pt. I, 106, 116-125, https://doi.org/10.1016/j.dsr.2015.08.010, 2015.

Pey, J., Querol, X., and Alastuey, A.: Variations of levels and composition of $\mathrm{PM}_{10}$ and $\mathrm{PM}_{2.5}$ at an insular site in the Western Mediterranean, Atmos. Res., 94, 285-299, https://doi.org/10.1016/j.atmosres.2009.06.006, 2009.

Pey, J., Querol, X., Alastuey, A., Forastiere, F., and Stafoggia, M.: African dust outbreaks over the Mediterranean Basin during 2001-2011: $\mathrm{PM}_{10}$ concentrations, phenomenology and trends, and its relation with synoptic and mesoscale meteorology, Atmos. Chem. Phys., 13, 1395-1410, https://doi.org/10.5194/acp13-1395-2013, 2013.

Polissar, A. V., Hopke, P. K., and Poirot, R. L.: Atmospheric aerosol over Vermont: chemical composition and sources, Environ. Sci. Technol., 35, 4604-4621, https://doi.org/10.1021/es0105865, 2001.

Pulido-Villena, E., Rérolle, V., and Guieu, C.: Transient fertilizing effect of dust in P-deficient LNLC surface ocean, Geophys. Res. Lett., 37, L01603, https://doi.org/10.1029/2009g1041415, 2010.

Putaud, J. P., Raes, F., Dingenen, R. V., Baltensperger, U., Brüggemann, E., Facchini, M. C., Decesari, S., Fuzzi, S., Gehrig, R., Hansson, H. C., Hüglin, C., Laj, P., Lorbeer, G., Maenhaut, W., Mihalopoulos, N., Müller, K., Querol, X., Rodríguez, S., Schneider, J., Spindler, G., ten Brink, H., Tørseth, K., Wehner, B., and Wiedensohler, A.: A European Aerosol Phenomenology. 2: chemical characteristics of particulate matter at kerbside, urban, rural and background sites in Europe, Atmos. Environ., 38, 2579-2595, https://doi.org/10.1016/j.atmosenv.2004.01.041, 2004.

Remoudaki, E., Bergametti, G., and Losno, R.: On the dynamic of the atmospheric input of copper and manganese into the Western Mediterranean Sea, Atmos. Environ., 25A, 733-744, https://doi.org/10.1016/0960-1686(91)90072-F, 1991.

Ribera d'Alcalà, M., Civitarese, G., Conversano, F., and Lavezza, R. C.: Nutrient ratios and fluxes hint at overlooked processes in the Mediterranean Sea, J. Geophys. Res.-Oceans, 108, 8106, https://doi.org/10.1029/2002jc001650, 2003.

Richon, C., Dutay, J.-C., Dulac, F., Wang, R., Balkanski, Y., Nabat, P., Aumont, O., Desboeufs, K., Laurent, B., Guieu, C., Raimbault, P., and Beuvier, J.: Modeling the impacts of atmospheric deposition of nitrogen and desert dust-derived phosphorus on nutrients and biological budgets of the Mediterranean Sea, Prog. Oceanogr., 163, 21-39, https://doi.org/10.1016/j.pocean.2017.04.009, 2018a.

Richon, C., Dutay, J.-C., Dulac, F., Wang, R., and Balkanski, Y.: Modeling the biogeochemical impact of atmospheric phosphate deposition from desert dust and combustion sources to the Mediterranean Sea, Biogeosciences, 15, 2499-2524, https://doi.org/10.5194/bg-15-2499-2018, 2018 b. 
Ridame, C., Guieu, C., and Löye-Pilot, M. D.: Trend in total atmospheric deposition fluxes of aluminium, iron, and trace metals in the northwestern Mediterranean over the past decade (1985-1997), J. Geophys. Res., 104, 30127-30138, https://doi.org/10.1029/1999JD900747, 1999.

Ridame, C., Le Moal, M., Guieu, C., Ternon, E., Biegala, I. C., L'Helguen, S., and Pujo-Pay, M.: Nutrient control of $\mathrm{N}_{2}$ fixation in the oligotrophic Mediterranean Sea and the impact of Saharan dust events, Biogeosciences, 8, 2773-2783, https://doi.org/10.5194/bg-8-2773-2011, 2011.

Salvador, P., Alonso-Pérez, S., Pey, J., Artíñano, B., de Bustos, J. J., Alastuey, A., and Querol, X.: African dust outbreaks over the western Mediterranean Basin: 11-year characterization of atmospheric circulation patterns and dust source areas, Atmos. Chem. Phys., 14, 6759-6775, https://doi.org/10.5194/acp14-6759-2014, 2014.

Sciare, J., Oikonomou, K., Favez, O., Liakakou, E., Markaki, Z., Cachier, H., and Mihalopoulos, N.: Long-term measurements of carbonaceous aerosols in the Eastern Mediterranean: evidence of long-range transport of biomass burning, Atmos. Chem. Phys., 8, 5551-5563, https://doi.org/10.5194/acp-8-5551-2008, 2008.

Sellegri, K., Gourdeau, J., Putaud, J.-P., and Despiau, S.: Chemical composition of marine aerosol in a Mediterranean coastal zone during the FETCH experiment, J. Geophys. Res., 106, 12023, https://doi.org/10.1029/2000JD900629, 2001.

Tanaka, T., Thingstad, T. F., Christaki, U., Colombet, J., CornetBarthaux, V., Courties, C., Grattepanche, J.-D., Lagaria, A., Nedoma, J., Oriol, L., Psarra, S., Pujo-Pay, M., and Van Wambeke, F.: Lack of P-limitation of phytoplankton and heterotrophic prokaryotes in surface waters of three anticyclonic eddies in the stratified Mediterranean Sea, Biogeosciences, 8, 525-538, https://doi.org/10.5194/bg-8-525-2011, 2011.

Tovar-Sánchez, A., Duarte, C. M., Arrieta, J. M., and SañudoWilhelmy, S.: Spatial gradients in trace metal concentrations in the surface microlayer of the Mediterranean Sea, Frontiers Mar. Sci., 1, 9, https://doi.org/10.3389/fmars.2014.00079, 2014.
Vincent, J., Laurent, B., Losno, R., Bon Nguyen, E., Roullet, P., Sauvage, S., Chevaillier, S., Coddeville, P., Ouboulmane, N., di Sarra, A. G., Tovar-Sánchez, A., Sferlazzo, D., Massanet, A., Triquet, S., Morales Baquero, R., Fornier, M., Coursier, C., Desboeufs, K., Dulac, F., and Bergametti, G.: Variability of mineral dust deposition in the western Mediterranean basin and south-east of France, Atmos. Chem. Phys., 16, 8749-8766, https://doi.org/10.5194/acp-16-8749-2016, 2016.

Violaki, K., Sciare, J., Williams, J., Baker, A. R., Martino, M., and Mihalopoulos, N.: Atmospheric water-soluble organic nitrogen (WSON) over marine environments: a global perspective, Biogeosciences, 12, 3131-3140, https://doi.org/10.5194/bg-123131-2015, 2015.

Violaki, K., Bourrin, F., Aubert, D., Kouvarakis, G., Delsaut, N., and Mihalopoulos, N.: Organic phosphorus in atmospheric deposition over the Mediterranean Sea: An important missing piece of the phosphorus cycle. Special issue of MERMEX project: Recent advances in the oceanography of the Mediterranean Sea, Prog. Oceanogr., 163, 50-58, 2018.

Wai, K.-M., Wu, S., Li, X., Jaffe, D. A., and Perry, K. D.: Global Atmospheric Transport and Source-Receptor Relationships for Arsenic, Environ. Sci. Technol., 50, 3714-3720, https://doi.org/10.1021/acs.est.5b05549, 2016.

Waldner, P., Marchetto, A., Thimonier, A., Schmitt, M., Rogora, M., Granke, O., Mues, V., Hansen, K., Pihl Karlsson, G., Zlindra, D., Clarke, N., Verstraeten, A., Lazdins, A., Schimming, C., Lacoban, C., Lindroos, A.-J., Vanguelova, E., Benham, S., Meesenburg, H., Nicolas, M., Kowalska, A., Apuhtin, V., Napa, U., Lachmanová, Z., Kristoefel, F., Bleeker,A., Ingerslev, M., Vesterdal, L., Molina, J., Fischer, U., Seidling, W., Jonard, M., O'Dea, P., Johnson, J., Fischer, R., and Lorenz, M.: Detection of temporal trends in atmospheric deposition of inorganic nitrogen and sulphate to forests in Europe, Atmos. Environ., 95, 363-374, https://doi.org/10.1016/j.atmosenv.2014.06.054, 2014. 